\title{
A new method for the empirical conversion of logging data to clay mineral fraction in the Nankai accretionary prism
}

\author{
Suguru Yabe ${ }^{1 *}\left(\mathbb{D}\right.$, Rina Fukuchi ${ }^{2}$, Yohei Hamada ${ }^{3}$ and Gaku Kimura ${ }^{4}$
}

\begin{abstract}
Sediment lithology, especially the clay mineral fraction, is basic geologic information, which is important for understanding faulting and evolutionary process of the accretionary prism. During scientific drilling, the clay mineral fraction is measured using $X$-ray diffraction analyses of samples from the acquired cores. However, coring in an accretionary prism is sometimes difficult, which hinders the acquisition of clay mineral fraction data. This study details the development of a new method used to empirically estimate the clay mineral fraction from the electrical resistivity and natural gamma ray logs obtained from the Kumano section of the Nankai Tough, where multiple scientific drilling expeditions have been conducted. This method is composed of two steps. First, porosity is estimated using electrical resistivity logs. In order to compensate for the effect of porosity, the natural gamma ray logs are then normalized using (1 - porosity). Second, the normalized natural gamma ray logs are converted into clay mineral fractions using an empirical conversion function. This empirical function was determined by comparing all available normalized natural gamma ray logs and clay mineral fractions data collected from the Kumano section of the Nankai Trough. As a byproduct of the porosity estimations, thermal conductivity and temperature depth profiles were also estimated for all of the logging sites. As electrical resistivity logs and natural gamma ray logs are essential measurements made during scientific drilling, this new method can be applied to future drilling expeditions in the Nankai Trough. Although the empirical conversion function established in this study is valid only at the Kumano section of the Nankai trough, the same procedure can be applicable to other subduction zones to establish local empirical conversion functions if enough data are available. The clay mineral fraction depth profile estimated using this method can provide useful information for various geological studies, including sedimentology and structural geology of the shallow accretionary prism.
\end{abstract}

Keywords: Clay mineral fraction, Logging while drilling, Natural gamma ray log, Accretionary prism, Nankai Trough

\section{Introduction}

Understanding the lithology of sedimentary materials in accretionary prisms is important for a variety of reasons. It is basic sedimentological information and is useful for understanding the provenance of the material (e.g., Moore et al. 2015a, b; Pickering et al. 2013).

\footnotetext{
*Correspondence: s.yabe@aist.go.jp

${ }^{1}$ Geological Survey of Japan, National Institute of Advanced Industrial Science and Technology (AIST), Tsukuba Central 7, 1-1-1 Higashi, Tsukuba, Ibaraki 305-8567, Japan

Full list of author information is available at the end of the article
}

The mechanical properties of the sediment also change according to the lithology. The clay mineral fraction of the sediment is especially important, as sediment with a high clay mineral fraction has a weaker frictional strength, which influences the formation process of the shallow plate interface in an accretionary prism (Moore et al. 1986; Moore and Shipley 1988; Moore et al. 1990; Vrolijk 1990; Ujiie et al. 2003; Sawai et al. 2014; Oohashi et al. 2015; Hüpers et al. 2017). To determine the lithology of sediments in shallow accretionary prisms, scientific drilling is a useful tool. This study focuses on the Nankai Trough, where the International Ocean Discovery 
Program (IODP) has conducted multiple expeditions as part of the Nankai Trough Seismogenic Zone Experiment (NanTroSEIZE) using the drilling vessel (D/V) Chikyu (Tobin and Kinoshita 2006), which aimed to understand seismogenesis and evolutionary process of the Nankai trough.

Core samples and logging data are acquired during scientific drilling. The clay mineral fraction is measured from core samples using X-ray diffraction (XRD) analyses (Expedition 315 Scientists 2009a). Due to much effort (Expedition 319 Scientists 2010a; Guo and Underwood 2012; Saffer et al. 2017; Strasser et al. 2014a; Underwood 2017a, b, c; Underwood and Guo 2013, 2017; Underwood 2017a, b, c; Underwood and Song 2016; Yamaguchi et al. 2020), clay mineral assemblages have been determined and used to interpret the evolution of the accretionary prism (Underwood 2018; Underwood and Guo 2018). However, XRD data is limited by the fact that data cannot be acquired when core samples are not recovered. This is especially true in the accretionary prism, which is composed of easily collapsible sediment, and coring has sometimes been difficult due to poor hole conditions throughout the NanTroSEIZE project (Expedition 315 Scientists 2009b, Expedition 316 Scientists 2009a; Kitajima et al. 2020). In difficult drilling conditions, logging while drilling (LWD) techniques are more promising than coring. LWD can acquire data continuously without pauses in drilling, which is advantageous for maintaining satisfactory hole conditions. Among the acquired logging data, natural gamma ray (NGR) log data are used to infer the lithology of the drilled sediment. The NGR log measures the number of gamma rays encountered by the detector in the logging tool (e.g., Expedition 314 Scientists 2009a). If spectral NGR logs are available, which can distinguish the source elements of the gamma radiation (Expedition 319 Scientists 2010b), mineralogical modeling can be used to quantitatively estimate the downhole lithology (e.g., Hampson et al. 2005). However, this is not possible when NGR logs that count only the total amount of NGR radiation are available. In such a case, the values from the NGR logs are usually used as a qualitative index of shale content. Because NGR logs are highly dependent on the lithology and chemical composition of geological formations, which can vary widely, it is difficult to establish a general conversion method from NGR log data to the clay mineral fraction of the formation. However, if specific regions with a relatively common lithology are analyzed in detail, the NGR logs could be quantitatively related to the clay mineral fraction. Because logging data are acquired continuously with depth, a depth profile of the downhole clay mineral fraction could be estimated in more detail using logging data than from XRD analyses of core samples.
This study developed a new method to empirically estimate the sediment clay mineral fraction from logging data obtained from the Kumano section of the Nankai Trough. During NanTroSEIZE project, the spectral NGR logs are acquired only at one site, which hinders mineralogical modeling from logging data at other sites. Therefore, using logging data and core measurements acquired throughout the NanTroSEIZE project, we established an empirical conversion function from the NGR log data to the clay mineral fraction. Because the number of radioactive elements around the detector in the logging tool is affected by the porosity of the formation, we compensated for this effect by estimating the porosity structure from electrical resistivity logs using the method of Yabe et al. (2019).

In this paper, we provide a brief description of the tectonic setting in the Nankai Trough, compile all the available NGR logs from the NanTroSEIZE project, compare the porosity-normalized NGR logs with the clay mineral fractions measured from core samples to establish an empirical conversion function between the two, and show that the estimated clay mineral fraction depth profiles can be used for discussions of various aspects, including sedimentology and structural geology.

\section{Tectonic setting and data}

The Nankai trough is located off the coast of southwest Japan, where the Philippine Sea Plate (PSP) subducts at a rate of $\sim 6 \mathrm{~cm} /$ year (Miyazaki and Heki 2001; DeMets et al. 2010; Kimura et al. 2018). During subduction, thick sediments on the incoming PSP have accreted onto the overriding plate, forming an accretionary prism. The Kumano transect, which is the main target of the NanTroSEIZE project (Tobin and Kinoshita 2006), is located off the Kii Peninsula. Seismic surveys and a series of IODP expeditions have been conducted along this transect to understand the geologic structure and history of this subduction zone (Fig. 1). The forearc prism is composed of inner and outer wedges separated by the outer ridge, where the megasplay fault intersects the seafloor (Kimura et al. 2007). The outer wedge formed rapidly after $2 \mathrm{Ma}$, when the megasplay fault became active (Strasser et al. 2009; Kimura et al. 2011; Moore et al. 2015a, b). In contrast, the inner wedge is composed of older sediments, suggesting that the inner wedge formed before $6 \mathrm{Ma}$ (Kimura et al. 2018). Uplift caused by motion along the megasplay fault forms a forearc basin on the inner wedge prism, which is called the Kumano Basin.

The sediments that make up the accretionary prism have hemipelagic and terrigenous sources. In the Nankai Trough, the incoming PSP is covered by thick hemipelagic sediment (Shikoku Basin sediment), whereas terrigenous sediments are transported into the margin 


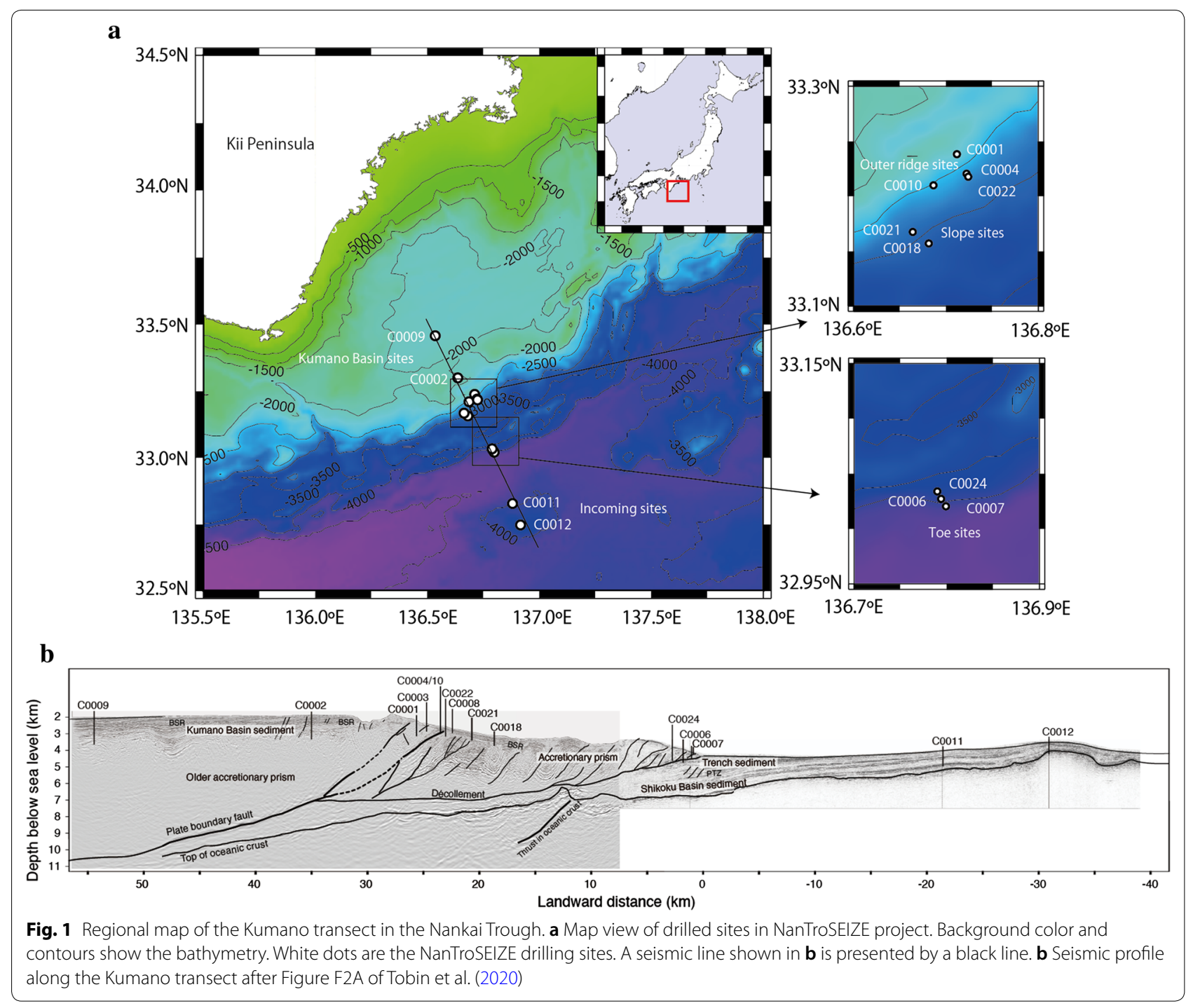

as trench wedge fill and slope apron facies. The geologic background of the Shikoku Basin sediments has been reviewed in detail by Underwood (2018). The Shikoku Basin formed in response to backarc rifting along the Izu-Bonin Arc at $30 \mathrm{Ma}$, and spreading continued until $\sim 15$ Ma (Okino et al. 1994, 1999; Sdrolias et al. 2004). Several bathymetric highs around the Shikoku Basin, which are related to basin formation, control the sediment supply into the basin. The Kinan seamount chain is the spreading axis of the Shikoku Basin and was volcanically active until approximately $7-8 \mathrm{Ma}$ (Ishii et al. 2000). The western side of the Shikoku Basin is defined by the Kyushu-Palau ridge, which is the remnant portion of the Izu-Bonin arc (Ishizuka et al. 2011). Although pelagic clays were deposited on the basaltic basement when the Shikoku Basin was located far offshore from the
Japan arc, terrigenous turbidite sediments mixed with the pelagic sediments as the PSP moved closer to the Japan arc. Two major turbidite facies are observed along the Kumano transect. The Kyushu Fan is a mixed turbidite facies observed above the pelagic clay layer along the entire Nankai Trough, with an age of $\sim 12-15 \mathrm{Ma}$ (Pickering et al. 2013). The Kyushu Fan deposits are thought to have been transported from the East China Sea, although the current route was cut at $\sim 7 \mathrm{Ma}$ by the opening of the Okinawa Trough (Underwood and Guo 2018). The Zenisu Fan is a volcanic turbidite facies observed only along the Kumano transect, with an age of 8-9 Ma (Pickering et al. 2013). The Zenisu Fan is thought to be a tuffaceous gravity flow produced by the Izu-Honshu collision zone (Underwood and Guo 2018). Along the Kumano transect, the Zenisu Fan sediments are called 
the Middle Shikoku Basin (MSB) sediments, and sediments above and below this unit are called the Upper and Lower Shikoku Basin (USB and LSB) sediments, respectively.

The NanTroSEIZE project has conducted ocean drilling in the various tectonic environments along the Kumano transect (Fig. 1). Two sites (C0011 and C0012) were drilled on the oceanic plate outside the subduction zone. Three sites (C0006, C0007, and C0024) were drilled at the prism toe, where subduction initiates. These sites were drilled through the plate boundary décollement. Sites C0018 and C0021 were drilled through the slope basin on the trench slope to determine past megathrust earthquake seismicity by analyzing the turbidites in this section. Four sites (C0001, C0004, C0010, and C0022) were drilled around the outer ridge near the seafloor intersection of the megasplay fault. Site C0001 is located on the hanging wall, while sites $\mathrm{C} 0004$ and $\mathrm{C} 0010$ were drilled through the megasplay fault. Site C0022 is located in the slope basin, where the megasplay fault extension is expected to pass through. Sites $\mathrm{C0002}$ and $\mathrm{C0009}$ are located in the Kumano Basin. Site C0002 is the deepest hole of all the sites drilled during the NanTroSEIZE project, with a depth of $\sim 3265$ mbsf.

\section{Gamma ray log normalization}

The NGR logs measure the gamma ray energy that radiates from radioactive elements in geologic formations (e.g., Expedition 314 Scientists 2009a). Because the radioactive elements are in the solid parts of the rocks, higher porosities result in decreased amounts of radioactive elements present around the detector, resulting in smaller NGR $\log$ values. Therefore, formations containing the same clay mineral fraction can exhibit different NGR log values according to their porosity, which makes it difficult for scientists to establish an empirical conversion function between NGR log values and the clay mineral fraction. To exclude this effect due to variations in porosity $(\phi)$ from the NGR variations, we calculated the normalized NGR, which is defined as the NGR value divided by $1-\phi$ (Hüpers et al. 2015). In this study, we applied a spatial smoothing of $10 \mathrm{~m}$ to the datasets used to smooth out fine-scale variations in logging data and depth shifts between logging holes and core holes.

To calculate the normalized NGR, porosity distributions were prepared using three different datasets. The first dataset is the porosity values measured onboard D/V Chikyu using the moisture and density (MAD) method (Expedition 315 2009a). As this method requires core samples, porosity was measured only at depths, where cores were recovered. In addition, because LWD and coring cannot be conducted at the same time in the same hole, there could be a depth shift between the core depth and the recorded logging depth.

The second dataset is porosities converted from electrical resistivity log data. Electrical resistivity is known to correlate empirically with porosity (Archie 1942). Although the thermal structure of the hole is required to convert the electrical resistivity into porosity, Yabe et al. (2019) developed a method to estimate the porosity and thermal structure simultaneously from electrical resistivity log data. In their method, porosity and thermal structure are estimated iteratively until they converge to values that satisfy correlations between porosity, thermal conductivity, and electrical resistivity. Their correlations between physical properties were also developed using measurements made onboard D/V Chikyu. Porosity is converted from the electrical resistivity log data using the assumed thermal structure and empirical relationships between electrical resistivity and porosity. The calculated porosity is further converted to thermal conductivity using the established relationship. Then, the thermal structure is updated based on the thermal conductivity structure and observed heat flow. Although a thermal steady state is assumed when calculating the thermal structure, corrections are applied to some sites according to the depositional history of each site using a correction factor $\alpha$. A detailed description of this process is described in Yabe et al. (2019). The iterative estimation process continues until the results converge. Yabe et al. (2019) applied this method to Site C0002 and showed that the estimated structures are consistent with the porosities and thermal conductivities measured in core samples, as well as with porosities calculated from density log data. In this study, we applied the method developed by Yabe et al. (2019) to all NanTroSEIZE sites, where electrical resistivity logs are available. The bit resistivity was used for the conversions in this study, because it usually has the greatest investigation depth among the acquired electrical resistivity logs and is less influenced by the drilling mud invasion effect and/or borehole conditions.

The third dataset is porosities converted from density $\log$ data. Because grain density and fluid density are estimated from shipboard MAD measurements as 2.7 and $1.0 \mathrm{~g} / \mathrm{cm}^{3}$, respectively (Yabe et al. 2019), density logs can be converted to porosities. Although it is the most reliable dataset measured in situ, density log data are only available for sites C0001, C0002, and C0009.

\section{Incoming sites}

Two sites (C0011 and C0012) are located on the PSP outside of the subduction zone (Fig. 1). Site C0011 is located at the foot of the Kashinosaki knoll, which represents the normal sedimentary stratigraphy of the PSP. Site C0012 is located on the Kashinosaki knoll, which is a topographic 
high related to volcanic activity. Hence, the sediments observed at site $\mathrm{C} 0012$ have been more influenced by heating than those at site C0011.

At site C0011, LWD was performed during IODP Expedition 322 (Expedition 322 Scientists 2010a), and coring was performed during both Expeditions 322 (Expedition 322 Scientists 2010a) and 333 (Expedition 333 Scientists 2012a). At site C0012, LWD was performed during IODP Expedition 338 (Strasser et al. 2014b) and coring was performed during Expeditions 322 (Expedition 322 Scientists 2010b) and 333 (Expedition 333 Scientists 2012b). According to the site reports, the stratigraphy can be divided into Upper, Middle, and LSB sediments, in addition to a thin pelagic claystone layer and the Kashinosaki Knoll basement below it (Fig. 2). USB sediments (Unit 1) are divided into two or three sub-units according to the abundance of ash layers. MSB sediments (Unit 2) are dominated by volcaniclastic sandstones. The Lower Shikoku Basin sediments are divided into three sub-units (Units 3-5). The upper unit is dominated by hemipelagic sediments, whereas the middle and lower units are rich in terrigenous components (Kyushu Fan sediments) and volcaniclastic-rich facies, respectively.

Porosity was estimated from the resistivity logs using heat flow values of $89.5 \mathrm{~mW} / \mathrm{m}^{2}$ at site C0011 (Expedition 333 Scientists 2012a) and $141 \mathrm{~mW} / \mathrm{m}^{2}$ (Expedition 333 Scientists 2012b) at C0012. Site C0012 exhibits a higher heat flow value, because it is located on the Kashinosaki Knoll, which was produced by local volcanic activity. As these sites are located far offshore and on the incoming plate, a sedimentation rate is slow enough to keep a thermal steady state. Therefore, no correction for thermal structure was applied.

Figure 2 shows the porosities, thermal conductivities, and thermal structures at sites C0011 and C0012. The porosities and thermal conductivities measured from the core samples are consistent with those estimated from the electrical resistivity logs. As the method developed by Yabe et al. (2019) only considers sedimentary material, the estimated values for the basaltic formations are not reliable. Although porosity and thermal conductivity exhibit a gradual decrease and increase with depth, respectively, they also exhibit a relatively sharp decrease and increase, respectively, at $\sim 250 \mathrm{mbsf}$ at site C0011 and at 70-125 mbsf at site C0012, which correspond to lithologic Unit 1B.

Figure 2 also shows the NGR log data and the clay mineral fractions. Clay mineral abundances at these sites have been reported previously by Underwood and Guo (2013, Underwood 2017a, b, c). The original NGR logs show an increasing trend with depth, although the normalized NGR logs show an almost constant or a slightly decreasing trend with depth, with several negative spikes. The negative spikes are especially prominent at $\sim 370-470$ mbsf at site C0011 and at $150-190$ mbsf at site C0012, which shipboard scientists interpreted as sand-rich layers of MSB sediment (Zenisu Fan sediments). Two large negative spikes around $700 \mathrm{mbsf}$ at site C0011 were also interpreted as sandy interbeds (Kyushu Fan sediments). The clay mineral fraction exhibits an increasing trend from $\sim 45 \%$ to $\sim 65 \%$ in the shallowest part of the sections (0-100 mbsf at site C0011 and 70 mbsf at site C0012). Below this layer, the clay mineral fraction is almost constant (around 60-70\%), except for the lower part of LSB sediments (Unit 4 and 5) showing scattering clay mineral fraction with interbedding sandy layers (Expedition 322 Scientists 2010b).

\section{Toe sites}

At site C0006, LWD was performed during IODP Expedition 314 (Expedition 314 Scientists 2009b) and coring was performed during Expedition 316 (Expedition 316 Scientists 2009a). At site C0024, LWD and coring were both performed during Expedition 358 (Yamaguchi et al. 2020). According to the site reports, the stratigraphy at these sites is divided into three lithologic units (Fig. 3). The upper unit is a thin slope apron facies. The middle unit is the accreted trench wedge sediment. The shallow part of this unit is composed of sandy coarse sediments, whereas the deeper part is composed of

\footnotetext{
(See figure on next page.)

Fig. 2 Data from the incoming sites. a Depth distributions of porosity, thermal conductivity, temperature, NGR, clay mineral fraction, and lithologic units at site C0011. Green symbols in the porosity, thermal conductivity, and clay mineral fraction plots represent data from core sample measurements. Red symbols in the porosity, thermal conductivity, and temperature plots indicate data estimated using the electrical resistivity logs. Black symbols in the NGR plot are the original (not normalized) NGR values, and green and red symbols are the NGR normalized using the MAD porosities and porosities estimated from the electrical resistivity logs, respectively. Red symbols in the clay mineral fraction plot are results estimated using the new method developed in this study. In the rightmost panel, USB, MSB, and LSB represent the upper, middle, and lower Shikoku Basin sediments, respectively. Lithological units colored by red represent the standard sediments, for which the empirical conversion function is established. Lithological units colored by green represent the upper part of USB sediments or the slope apron facies younger than $1.5 \mathrm{Ma}$, which shows higher normalized NGR log values than the standard sediments possibly due to volcanic ashes included in sediments. b Same as a, but for site C0012. Lithological units colored by gray are excluded from comparison in Fig. 7 due to poor data condition. c A seismic profile around incoming sites after Figure F2 of Expedition 333 Scientist (2012b)
} 

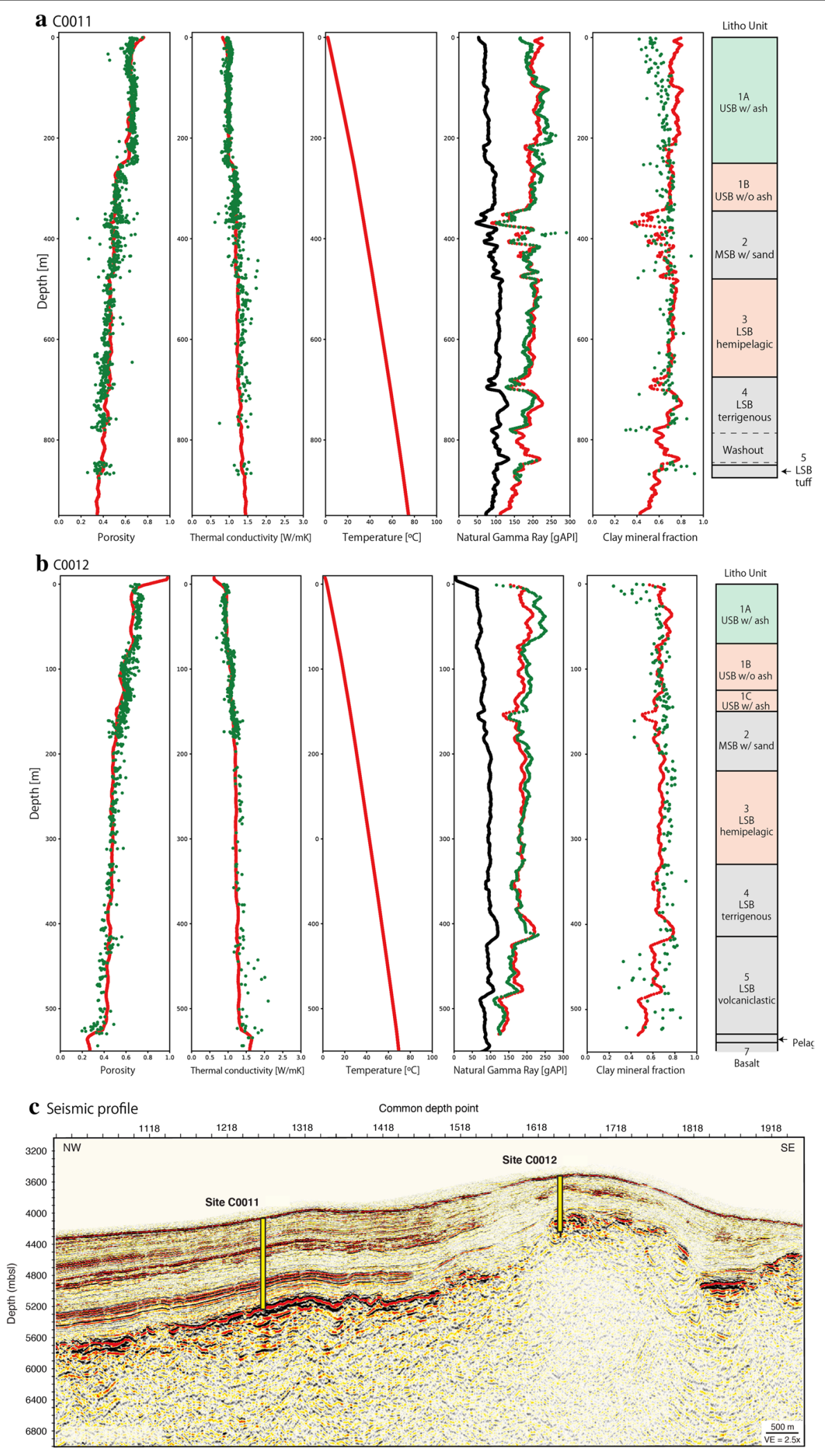

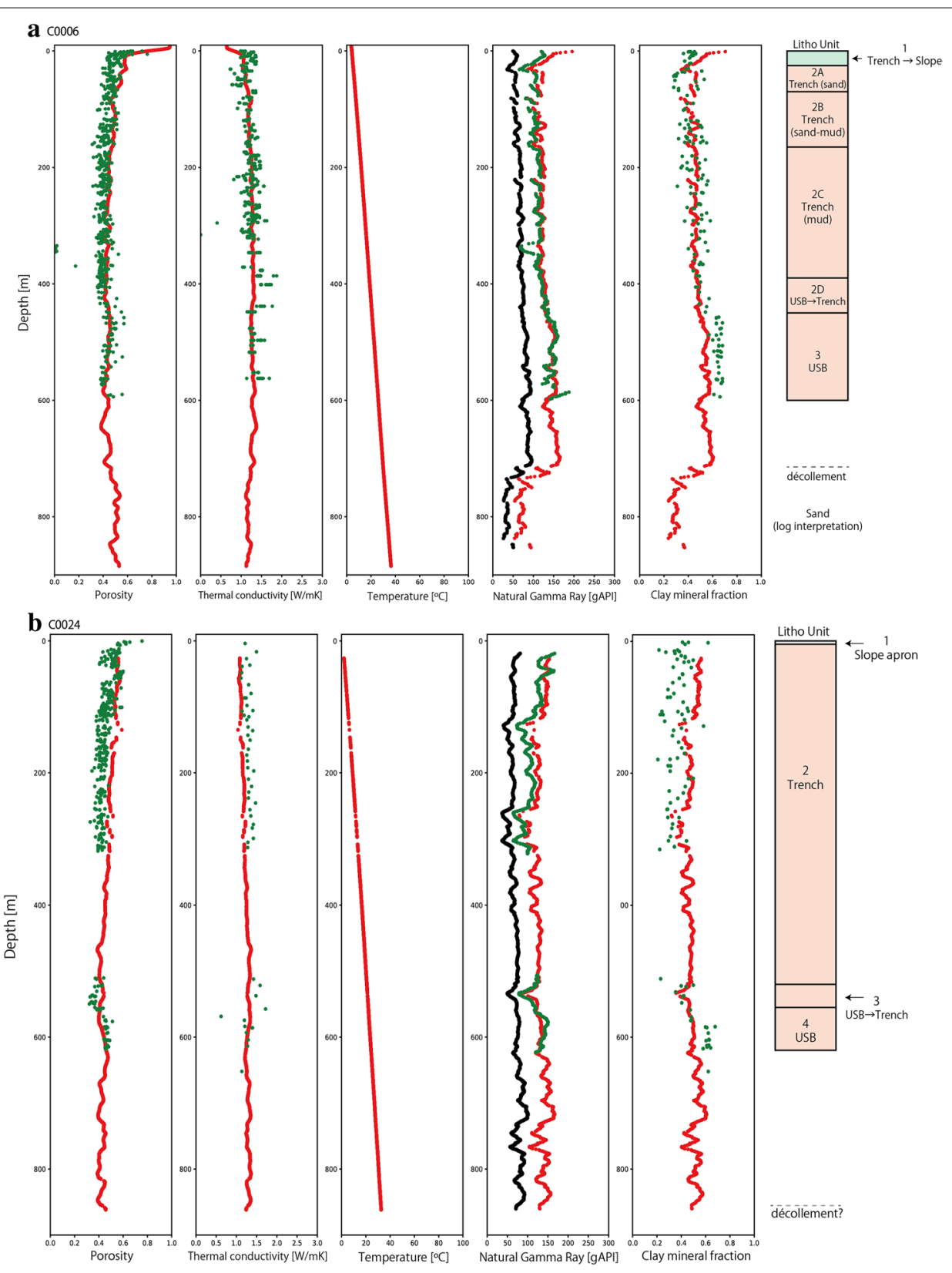

C Seismic profile
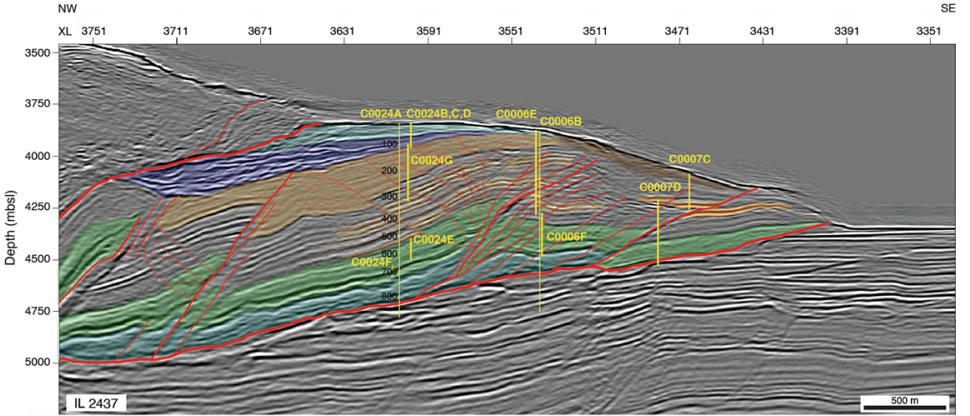

Fig. 3 Data from the toe sites. a Site C0006, b site C0024, and c a seismic profile around the prism toe after Figure F7 of Tobin et al. (2020). Symbols are the same as in Fig. 2 
muddy sediments. The lower unit is the accreted USB sediment. Although coring was successful only down to this unit, LWD successfully penetrated the potential décollement at $710 \mathrm{mbsf}$ at site $\mathrm{C0006}$ and at $\sim 850$ mbsf at site C0024.

The observed heat flow at site C0006 is very low $\left(\sim 35 \mathrm{~mW} / \mathrm{m}^{2}\right)$ (Expedition 316 Scientists 2009a; Harris et al. 2011). However, according to Harris et al. (2011), the heat flow value corrected for the effects of bathymetry and rapid sedimentation was $45 \mathrm{~mW} /$ $\mathrm{m}^{2}$. Hence, we used this value to estimate the porosity using the resistivity log data. We set the thermal structure correction factor $\alpha$ to 0.8 at the seafloor, and it was linearly increased to 1.0 at $25 \mathrm{mbsf}$, where the boundary between Units 1 and 2 is estimated. This was done, because Unit 1 had a rapid sedimentation rate as it accumulated at the slope apron (Expedition 316 Scientists2009a). In contrast, the observed heat flow at site C0024 is high $\left(\sim 98 \mathrm{~mW} / \mathrm{m}^{2}\right)$ (Yamaguchi et al. 2020). No correction for thermal structure was applied, because the slope apron facies unit at site $\mathrm{C} 0024$ is very thin.

Figure 3 shows the porosities, thermal conductivities, and thermal structures of sites C0006 and C0024. The porosities and thermal conductivities measured from the core samples are in good agreement with the values estimated at site C0006, whereas they show systematic differences at site C0024, which could be due to insufficient information on the heat flow and thermal structure of this site. Porosity exhibits a slightly decreasing trend in the accreted trench sediments. The porosity then remains almost constant, with some fluctuations in the accreted USB sediments. Porosity increases from 0.4 to 0.5 across the potential décollement at site C0006, whereas this increase is not observed at site C0024.

Figure 3 also shows the NGR log data and the clay mineral fraction. Clay mineral abundances at these sites have been previously reported by Guo and Underwood (2012) and Yamaguchi et al. (2020). Both the original and normalized NGR logs at C0006 show constant values in the accreted trench wedge sediment, which increase in the transitional unit from the trench wedge sediment to the USB sediment. The clay mineral fraction also increases rapid from 40 to $50 \%$ to $60-70 \%$ at the boundary between these two units. The clay mineral fraction of the accreted USB sediment is consistent with those of the incoming sites. The original and normalized NGR logs show a dramatic drop at the possible décollement at site C0006, where the estimated porosity also increases. The low NGR values observed below this depth have been interpreted as underthrust sand layers (Expedition 314 Scientists 2009b).

\section{Slope sites}

At site C0018, LWD was performed during IODP Expedition 338 (Strasser et al. 2014c), and coring was performed during Expedition 333 (Expedition 333 Scientists 2012c). At site C0021, LWD and coring were performed during Expedition 338 (Strasser et al. 2014d). According to the site reports, the stratigraphy at these sites consists of a single lithologic unit (Fig. 4). These sites are located on the slope basin, and the entire drilled section is slope basin sediments. The single unit is further divided into two sub-units according to the sand content.

Porosity was estimated from the resistivity log using heat flow values of $62 \mathrm{~mW} / \mathrm{m}^{2}$ at site C0018 (Expedition 333 Scientists 2012c) and $55 \mathrm{~mW} / \mathrm{m}^{2}$ at site C0021. We used a lower heat flow at site C0021, because it is located $\sim 2 \mathrm{~km}$ landward of site C0018. This value is consistent with the heat flow estimated using bottom-simulating reflector (BSR) in this region (Ohde et al. 2018). As no detailed information on the bathymetric and sedimentation rate corrections for the heat flow value are available for these sites, no thermal structure corrections were applied.

Figure 4 shows the porosities, thermal conductivities, and thermal structures at sites C0018 and C0021. The porosities and thermal conductivities measured from core samples are consistent with those estimated from the electrical resistivity logs. The porosities and thermal conductivities show simple decreasing and increasing trends with depth, respectively, with some fluctuations. Figure 4 also shows the NGR logs and clay mineral fractions. Clay mineral abundances at these sites have been reported previously by Underwood (2017a). The original NGR logs from site C0018 have almost constant values with several fluctuations. On the other hand, site C0021 exhibits an increasing trend with depth. A negative spike in the original NGR logs around $210 \mathrm{mbsf}$ is interpreted as interbedding sandy layer (Strasser et al. 2014c). The normalized logs from site C0018 decrease across the subunit boundary, which corresponds to a higher sand content in the lower sub-unit. The clay fraction in the lower sub-unit exhibits lower values than those of the upper sub-unit, though they are scattered and include some higher values. In contrast, the normalized NGR logs from site C0021 exhibit almost constant values, with some fluctuations. Clay mineral abundances were measured in samples from the upper sub-unit only.

\section{Outer ridge sites}

At sites C0001 and C0004, LWD was performed during IODP Expedition 314 (Expedition 314 Scientists 2009c, d) and coring was performed during Expedition 315 (Expedition 315 Scientists 2009b; Expedition 316 Scientists 2009b). At site C0010, LWD was performed 

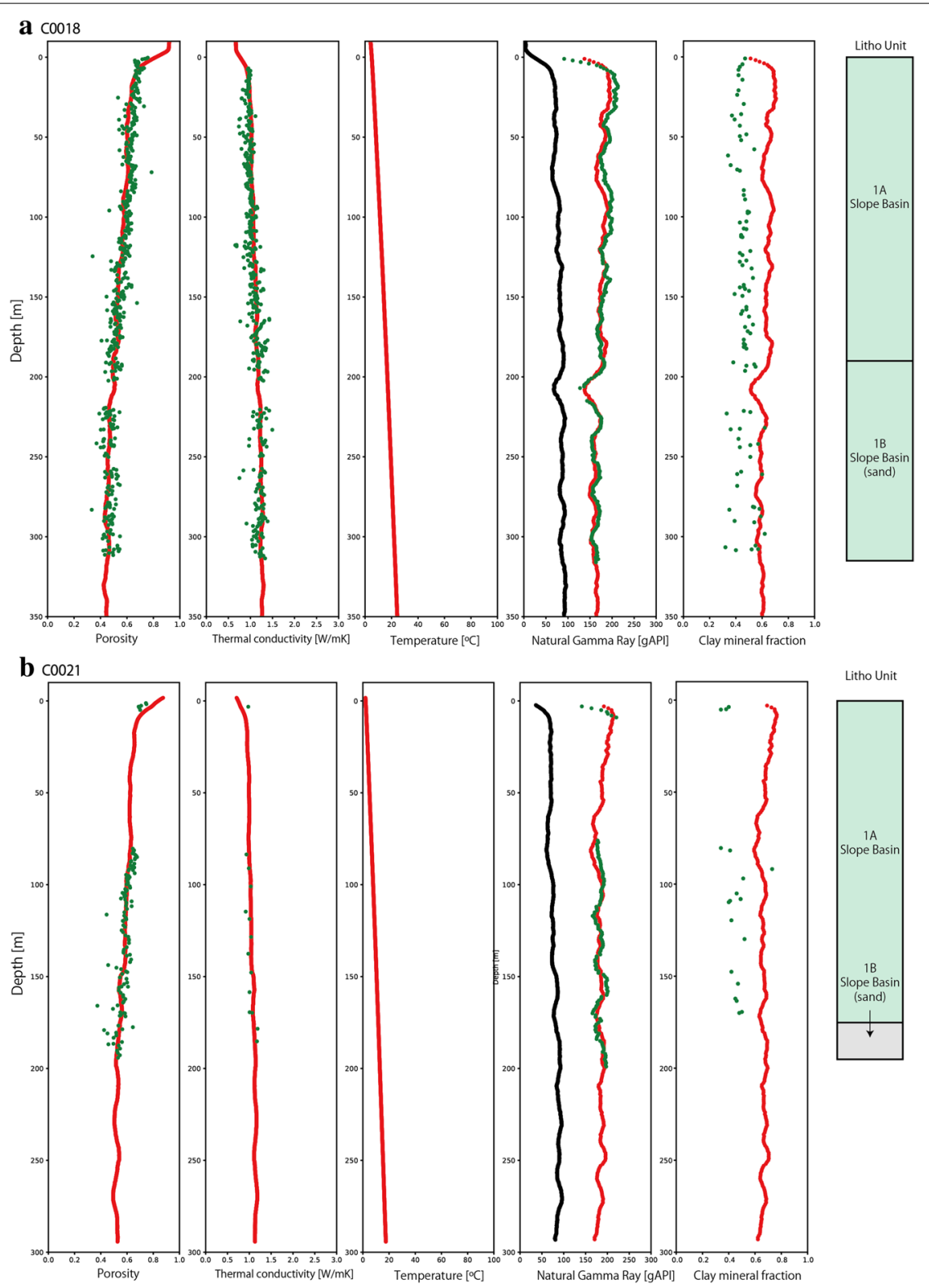

Litho Unit

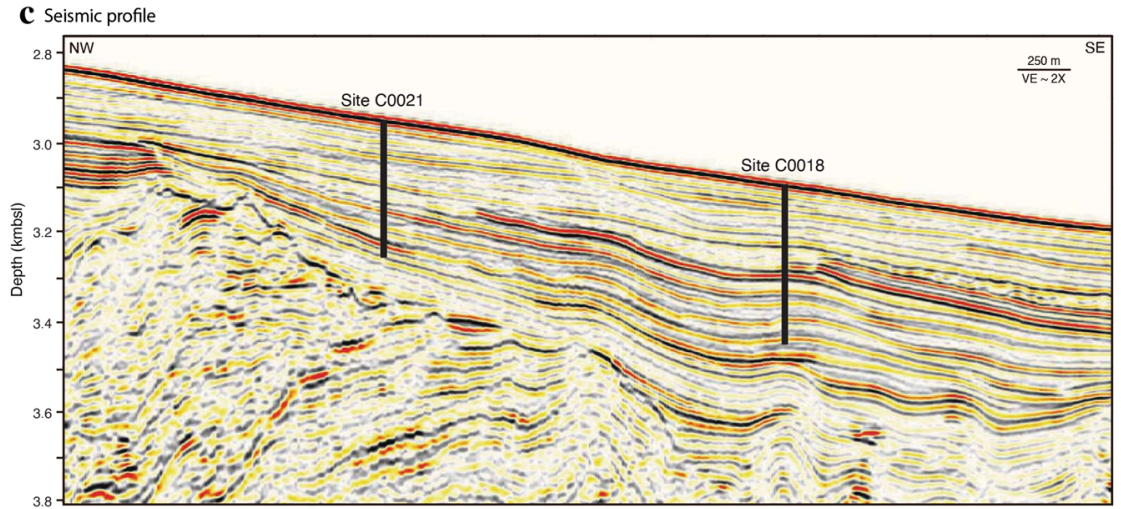

Fig. 4 Data from the slope sites. a Site C0018, b site C0021, and c a seismic profile around the slope apron after Figure F3 of Strasser et al. (2014d). Symbols are the same as in Fig. 2 


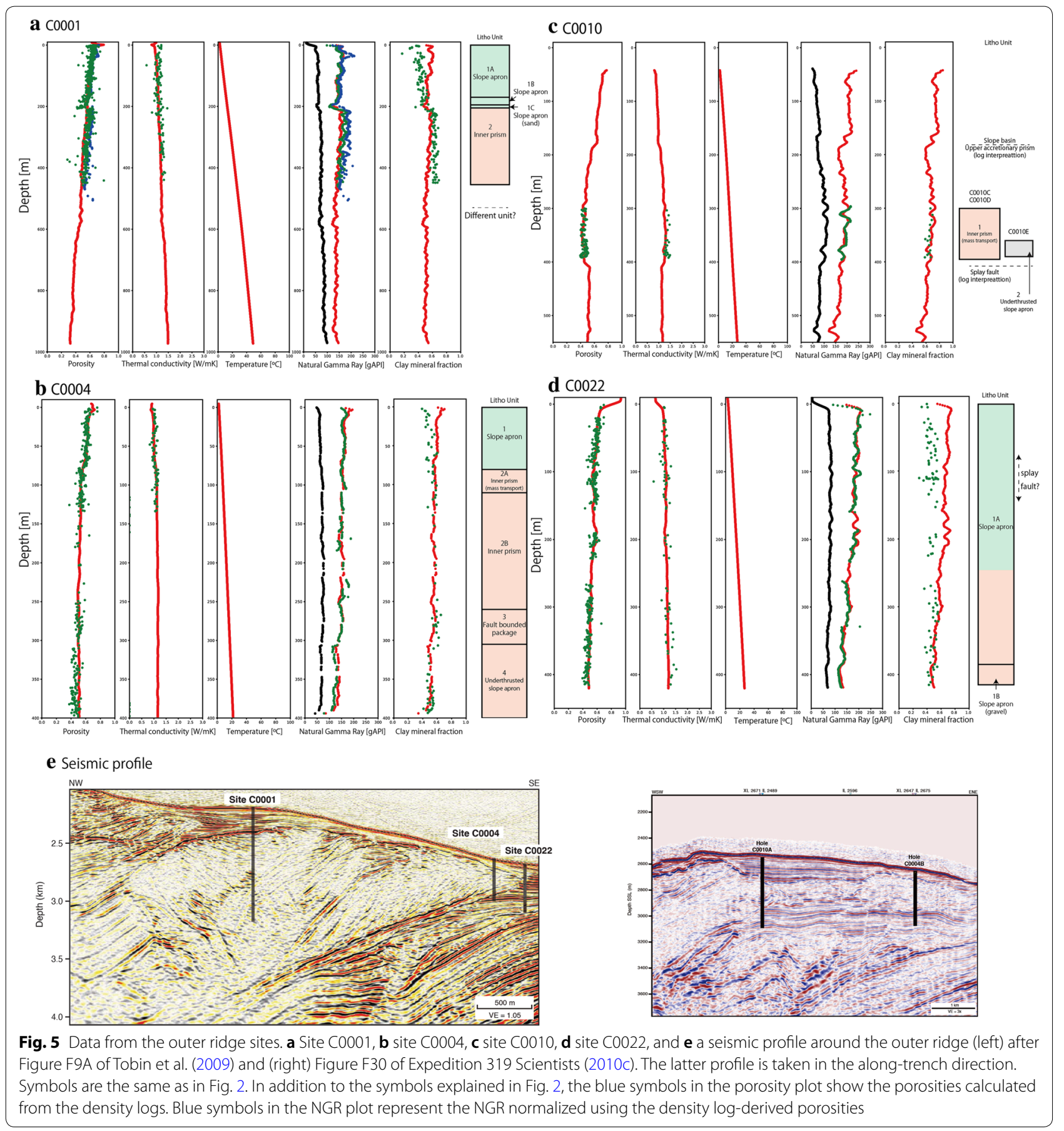

during Expedition 319 (Expedition 319 Scientists 2010c) and coring was performed during Expedition 365 (Saffer et al. 2017). At site C0022, LWD and coring were performed during Expedition 338 (Strasser et al. 2014a). Sites C0004, C0010, and C0022 were drilled through the splay fault, whereas site C0001 was drilled only through the hanging wall. According to the site reports, the stratigraphy of the hanging wall consists of two lithologic units (Fig. 5): the slope apron facies and the accreted inner prism sediments. As ash layers are rare in the inner prism sediments, which are frequently included in USB sediments, shipboard scientists interpreted this unit as the trench fill deposited during a period of low sand-silt influx, such as Unit $2 \mathrm{C}$ or $2 \mathrm{D}$ at site C0006. The footwall of the splay fault is the underthrust slope apron facies observed at sites C0004 
and C0010. A fault-bounded section is also observed around the splay fault at site C0004.

The observed heat flow at these sites is low: $47 \mathrm{~mW} /$ $\mathrm{m}^{2}$ at site C0001 (Expedition 315 Scientists 2009b; Harris et al. 2011) and $54-60 \mathrm{~mW} / \mathrm{m}^{2}$ at site C0004 (Expedition 314 Scientists 2009d; Harris et al. 2011). However, according to Harris et al. (2011), the heat flow value corrected for the bathymetry and rapid sedimentation effects was $60 \mathrm{~mW} / \mathrm{m}^{2}$ at both sites. Therefore, we used this value to estimate the porosities from the resistivity log data at sites C0001 and C0004. We also used this value at site $\mathrm{C} 0022$, as it is consistent with the heat flow estimated using BSR in this region (Ohde et al. 2018). We used a heat flow of $54 \mathrm{~mW} / \mathrm{m}^{2}$ at site $\mathrm{C} 0010$ (Expedition 319 Scientists 2010c). Although this value is slightly lower than the value used for the other sites, we used this value, because site $\mathrm{C} 0010$ is located westward of the other sites. This value is also consistent with the heat flow estimated using BSR in the region (Ohde et al. 2018). We only set the thermal structure correction factor $\alpha$ at site C0001 to 0.77 at the seafloor and it was linearly increased to 1.0 at $205 \mathrm{mbsf}$, where the boundary between Units 1 and 2 is estimated to occur, because Unit 1 has a rapid sedimentation rate and accumulated in the trench (Expedition 315 Scientists 2009b).

Figure 5 shows the porosities, thermal conductivities, and thermal structures at sites C0001, C0004, C0010, and C0022. The porosities and thermal conductivities measured from the core samples are consistent with those estimated from the electrical resistivity logs, although they show slight differences in Unit 2 at site C0001, which could be due to an insufficient thermal structure correction. A step increase in porosity is observed across the unit boundary between the slope apron facies and the inner prism at site C0001, whereas it is not observed at site C0004.

Figure 5 also shows the NGR logs and clay mineral fractions. Clay mineral abundances at these sites have been previously reported by Guo and Underwood (2012), Saffer et al. (2017), and Strasser et al. (2014a). At site C0010, we only used the clay mineral fractions from Holes C0010C and C0010D, because Hole C0010E contains data from the underthrust sediments, even though the logged hole is within the inner prism unit at this depth interval. The NGR value could be lower than the true value due to poor hole conditions at several depth intervals $(530-590,625-650,730-750,780-860$, and 900-925 mbsf) at site C0001 (Expedition 314 Scientists 2009c). In the slope apron facies, the original NGR logs show an increasing trend with depth, whereas the normalized NGR logs show almost constant values or a slightly decreasing trend with depth. The clay mineral fraction correspondingly increases from $\sim 35$ to $~ 45 \%$. At site C0001, both the original and normalized NGR logs show a step increase across the unit boundary between the slope apron facies and the inner prism sediments. The clay mineral fraction increases correspondingly at this depth from 45 to $65 \%$. However, such an increase was not observed at site C0004. In contrast, the normalized NGR values decrease in the underthrust slope apron facies at sites $\mathrm{C} 0004$ and $\mathrm{C0010}$. The clay mineral fraction decreases correspondingly to $\sim 45 \%$ at site C0004.

\section{Kumano basin sites}

At site C0002, LWD was performed during IODP Expeditions 314, 338, 348, and 358 (Expedition 314 Scientists 2009e; Strasser et al. 2014e; Tobin et al. 2015a; Kitajima et al. 2020) and coring was performed during Expeditions 315 and 338 (Expedition 315 Scientists 2009c; Strasser et al. 2014e). During Expeditions 348 and 358, short cores were also recovered. During Expeditions 338, 348, and 358, cutting samples were recovered during LWD (e.g., Tobin et al. 2015b). At site C0009, wireline logging was conducted during IODP Expedition 319 (Expedition 319 Scientists 2010a). According to the site reports, the stratigraphy of these sites is categorized into three lithologic units (Fig. 6). The upper unit is the Kumano Basin sediments, which are terrigenous sediments that accumulated behind the uplifting outer ridge. The middle unit is the slope apron facies, which was deposited before the uplift of the outer ridge occurred. The lower unit is the inner prism sediments.

The observed heat flow at site C0002 is low at $\sim 40 \mathrm{~mW} /$ $\mathrm{m}^{2}$ (Expedition 315 Scientists 2009c; Harris et al. 2011). However, according to Harris et al. (2011), the heat flow value corrected for bathymetry and rapid sedimentation effects was $57 \mathrm{~mW} / \mathrm{m}^{2}$. This value is consistent with the value estimated by Sugihara et al. (2014). Therefore, we used this value to estimate the porosities using the resistivity logs. We set the thermal structure correction factor $\alpha$ to 0.78 at the seafloor, and it was linearly increased to 1.0 at $830 \mathrm{mbsf}$, where the unit boundary between Units 2 and 3 is estimated to occur, because the Kumano Basin sediments have a rapid sedimentation rate (Expedition 315 Scientists 2009c). As this site was investigated previously by Yabe et al. (2019), refer to their study for details. At site C0009, wireline logging was conducted only in the deeper part of the hole, which prohibited the application of the method developed by Yabe et al. (2019) at this site. Instead, we refer to the porosities estimated from the density log data.

Figure 6 shows the porosities, thermal conductivities, and thermal structures at site C0002. At site C0002, the porosities and thermal conductivities measured from core samples are consistent with those estimated from the electrical resistivity logs above $\sim 1100$ mbsf. 

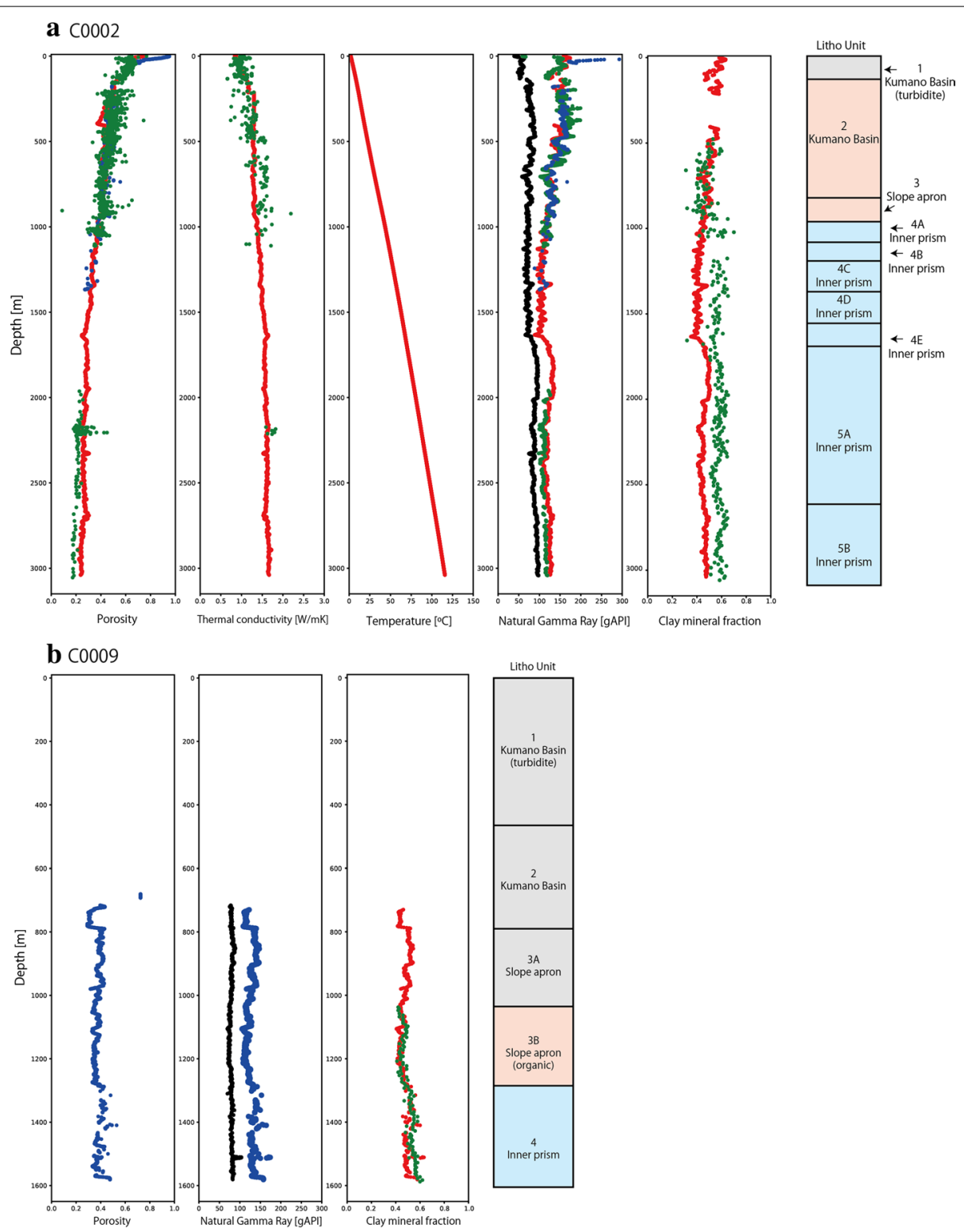

c Seismic profile

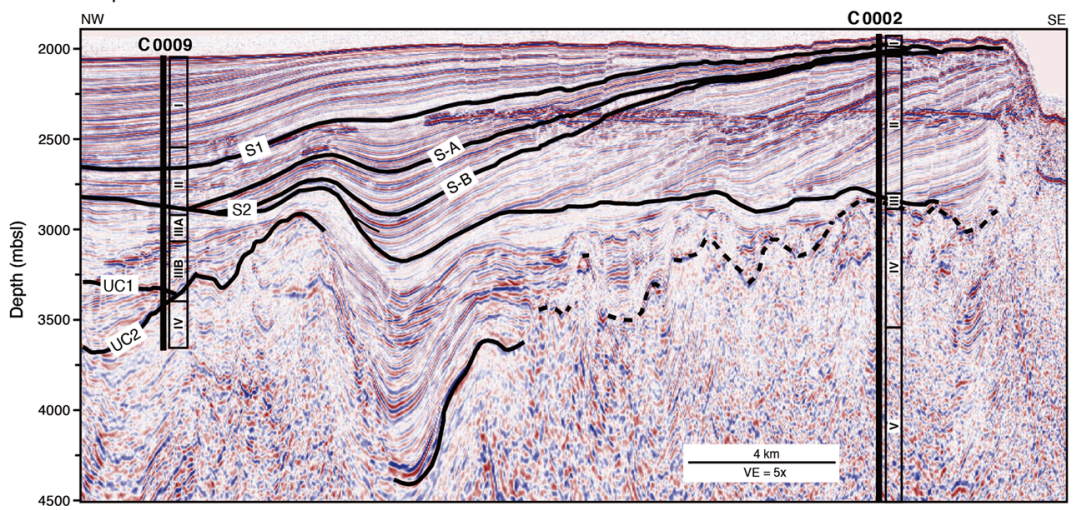

Fig. 6 Data from the Kumano Basin sites. a Site C0002, b site C0009, and c a seismic profile around the Kumano Basin after Figure F116 of Expedition 319 Scientist (2010a). Symbols are the same as those in Figs. 2 and 5. Lsithological units colored by light blue represent the inner prism sediment below the Kumano Basin, which shows lower NGR log values than the standard sediments possibly due to poor hole condition 

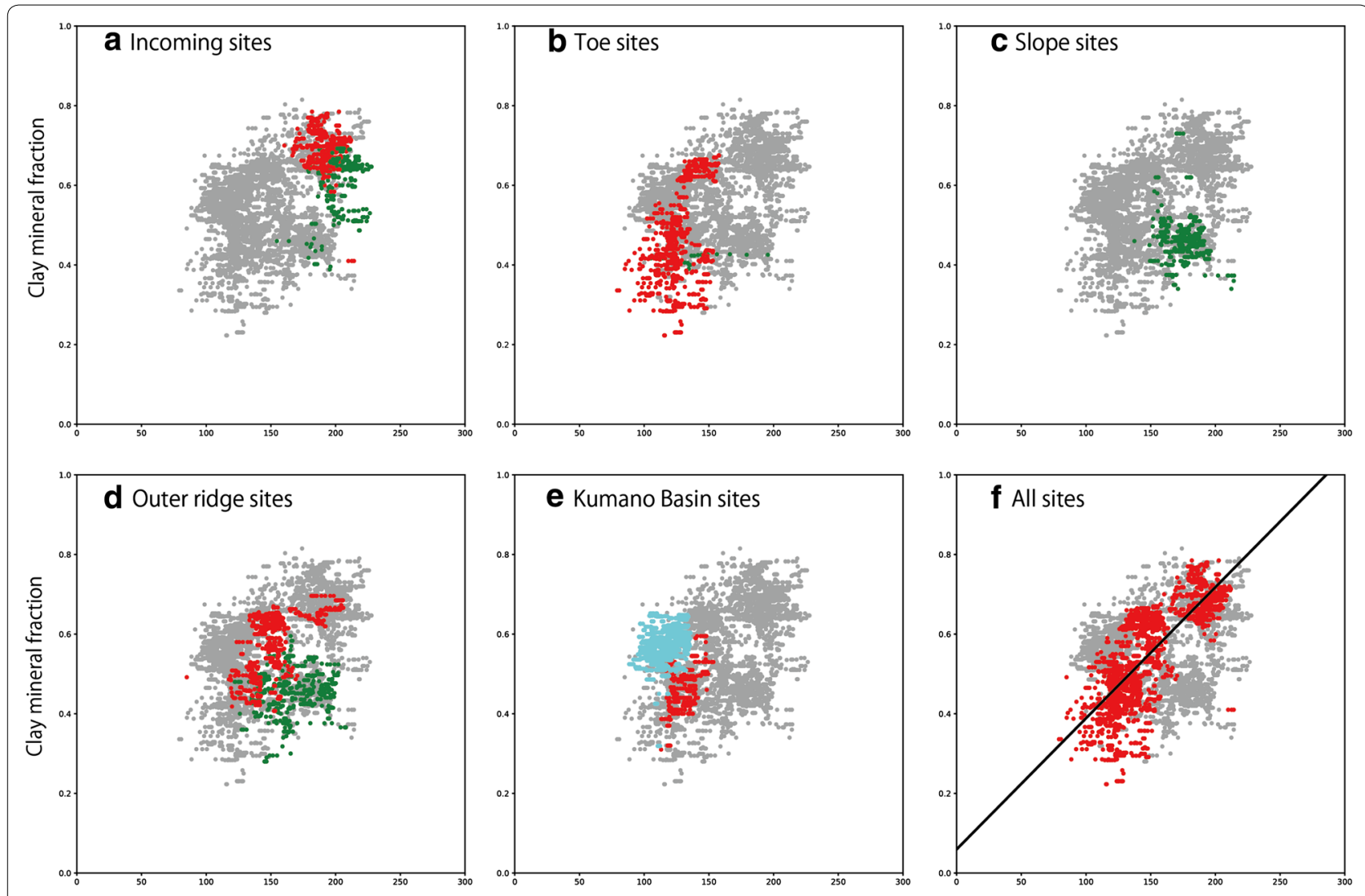

NGR logs normalized by porosity estimated from electrical resistivity logs [gAPI]

Fig. 7 Comparison between the NGR logs normalized using porosity estimated from the electrical resistivity logs and the clay mineral fractions. The panels show results from the $\mathbf{a}$ incoming sites, $\mathbf{b}$ toe sites, $\mathbf{c}$ slope sites, $\mathbf{d}$ outer ridge sites, e Kumano Basin sites, and $\mathbf{f}$ all sites combined. Color code (red, green, and light blue) for dots in Fig. 7 is common to that used for lithological units in Figs. 2, 3, 4, 5, 6. Red dots represent the standard sediments, for which the empirical conversion function is established. Green dots represent the upper part of USB sediments or the slope apron facies younger than $1.5 \mathrm{Ma}$, which shows higher normalized NGR log values than the standard sediments possibly due to volcanic ashes included in sediments. Light blue dots are the inner prism sediment below the Kumano Basin, which shows lower NGR log values than the standard sediments possibly due to poor hole condition. Grey dots indicate all data

Below 2000 mbsf, porosity was measured mainly from cutting samples, and is roughly consistent with the values estimated using resistivity logs, although there are some differences. Yabe et al. (2019) discussed this previously in further detail.

Figure 6 also shows the NGR logs and clay mineral fractions. Clay mineral abundances at these sites have been previously reported by Guo and Underwood (2012), Underwood and Song (2016), Underwood (2017b, c), and Expedition 319 Scientists (2010a). In the Kumano Basin sediments at site C0002, the original and normalized NGR logs exhibit a decreasing trend with depth below $\sim 500$ mbsf. Correspondingly, the clay mineral fraction decreases from $\sim 55 \%$ at $\sim 500 \mathrm{mbsf}$ to $\sim 45 \%$ at $\sim 830 \mathrm{mbsf}$. The normalized NGR log from site C0009 also exhibits a change in trend in the slope apron facies. The clay mineral fraction also decreases from $50 \%$ at $\sim 1100 \mathrm{mbsf}$ to $40 \%$ at $\sim 1200 \mathrm{mbsf}$, then increases to $50 \%$ at $\sim 1300 \mathrm{mbsf}$.

\section{Normalized gamma ray logs vs. clay mineral fractions}

In this section, the normalized gamma ray logs calculated in the previous section are compared with the clay mineral fractions measured from the core and cutting samples. We estimated the porosity in three ways (MAD porosity, porosity estimated from electrical resistivity logs, and porosity estimated from density logs). The three types of estimated porosities generally exhibited good agreement with each other, as shown in the porosity depth profiles (Figs. 2, 3, 4, 5, 6). Therefore, we used the NGR logs normalized by the resistivity log derived porosity as representative data (Fig. 7), because logging data represent the bulk rock values for the borehole. 
Comparisons with NGR logs normalized using the other estimated porosity types are shown in the supplementary figures (Additional files 1, 2: Figures S1 and S2), although our conclusions below remain the same.

Figure 7 shows the relationship between the normalized NGR logs and the clay mineral fraction in each geologic environment. At the incoming sites (Fig. 7a), the normalized NGR values and clay mineral fractions are $\sim 150-200$ gAPI and $60-80 \%$, respectively (red plots in Fig. 7a). An exception is Unit 1A of the USB sediments (green plots in Fig. 7a), which has a lower clay mineral fraction (50-65\%), although the normalized NGR values exceeded 200 gAPI. MSB sediments were excluded from this comparison, because the Zenisu Fan is composed of sandy sediments, as suggested by their low NGR values, although only a few measurements of the clay mineral fraction indicate low values. This could be due to a sampling bias of the clay mineral abundance measurements. Units 4 and 5 of the LSB sediments were also excluded from this comparison, because the clay mineral fractions measured from core samples exhibited scattered values possibly due to interbedding sandy layers (Expedition 322 Scientists 2010b).

The toe sites cover a wide range of normalized NGR values and clay mineral fractions (Fig. 7b). The trench wedge facies exhibit values of $\sim 100$ gAPI and $\sim 40 \%$, whereas the accreted USB sediments have values of $\sim 150$ gAPI and $\sim 65 \%$. Trends observed at the toe sites can extend to the higher values observed at the incoming sites. On the other hand, the slope sites deviated from this trend (Fig. 7c). The clay mineral fraction at the slope sites is low $(\sim 45 \%)$, because they consist of slope apron facies, although they exhibit high normalized NGR values of 150-200 gAPI. Similar trends were observed at the outer ridge sites (Fig. 7d). Slope apron facies at the top of the formation that are younger than $1.5 \mathrm{Ma}$ (Expedition 333 Scientists 2012c; Strasser et al. 2014d), have low clay mineral fractions, but exhibit high normalized NGR values (green dots in Fig. 7d). On the other hand, the inner prism sediments exhibit normalized NGR values of $\sim 150$ gAPI and clay mineral fractions of $\sim 65 \%$, which are similar to the values of the accreted USB sediments found at the toe sites (red dots in Fig. 7d). The slope apron facies at site C0022 older than $1.5 \mathrm{Ma}$ (Strasser et al. 2014a) and underthrust sediments at site $\mathrm{C0004}$, which are also older than $1.5 \mathrm{Ma}$ (Expedition 316 Scientists 2009b), exhibit normalized NGR values of $\sim 120$ gAPI and clay mineral fractions of $\sim 50 \%$, which are close to the values of the accreted trench wedge sediments found at the toe sites (red dots in Fig. 7d). The Kumano Basin sediments also exhibit similar values as the accreted trench wedge sediments found at the toe sites (Fig. 7e). The Kumano Basin sediments examined here are located below $500 \mathrm{mbsf}$ at site C0002, and have ages of $\sim 1.5 \mathrm{Ma}$ or older. The inner prism sediments below the Kumano Basin sediments deviate from the overall trend of the data. They have a relatively high clay mineral fraction of $50-65 \%$, although the normalized NGR values are small, at $\sim 100$ gAPI (light blue dots in Fig. 7e). However, this deviation in the inner prism below the Kumano Basin sediments is less evident at site C0009 (Additional file 2: Figure S2). The clay mineral fraction of the inner prism sediments found at site C0009 is 55\%, which is close to the value at site C0002. However, NGR values normalized by porosity estimated from the density logs are $\sim 140$ gAPI, which is much higher than those at site $\mathrm{C0002}$ (Fig. 6). Inner prism sediments at site C0001 also exhibit normal NGR values (Fig. 5). Hence, the low NGR values observed at site C0002 could be due to poor hole conditions (Expedition 314 Scientists 2009e; Tobin et al. 2015a).

Although the datasets compiled herein are scattered and contain some exceptions (Unit 1A of the USB sediments and slope apron sediments younger than $\sim 1.5 \mathrm{Ma}$, which are presented by green dots in Fig. 7, and inner prism sediments below the Kumano Basin sediments, which are presented by light blue dots in Fig. 7), they show a roughly linear relationship between the normalized NGR log values and the clay mineral fraction (red dots in Fig. 7). The scattering may be attributed to several factors, such as variable borehole conditions, minor differences in the lithology of a stratigraphic unit, insufficient calibration, and different spectral detectability of the logging tools. However, the overall trend shows a clear linear relationship between the normalized NGR values and the clay mineral fraction. We used this relationship to establish an empirical conversion function between the normalized NGR logs and the clay mineral fractions by applying least-square fitting of a linear function. We weighted the data using 1 - porosity when applying the fit, because higher porosities produce larger uncertainties in the normalized NGR logs. The conversion function was estimated to be:

$$
\begin{aligned}
& \text { Clay mineral fraction } \\
& \quad=3.3( \pm 1.0) \times 10^{-3} \times \mathrm{NGR}+0.06( \pm 0.15)
\end{aligned}
$$

when using porosity estimated from the electrical resistivity logs (Fig. 7f). The coefficient of determination is 0.60 . When using MAD porosity, the conversion function was estimated to be (Additional file 1: Figure S1):

Clay mineral fraction

$$
=2.9( \pm 0.8) \times 10^{-3} \times \mathrm{NGR}+0.12( \pm 0.12)
$$


with the coefficient of determination of 0.68 and for porosity estimated from density logs (Additional file 2: Figure S2) the conversion function was estimated to be

$$
\begin{aligned}
& \text { Clay mineral fraction } \\
& \quad=2.6( \pm 2.2) \times 10^{-3} \times \mathrm{NGR}+0.14( \pm 0.30)
\end{aligned}
$$

with the coefficient of determination of 0.75 . Those conversion functions are consistent with each other within the fitting uncertainties. Although the coefficient of determination is highest for the equation based on porosity estimated from density logs (Eq. 3), the uncertainty for the estimated parameters is largest. This is due to the lesser amount of data for density logs. The standard deviations for fitting residuals are about $5-8 \%$ in every case. With these conversion functions, we can estimate the clay mineral fraction at depth intervals, where only logging data are available.

The predicted clay mineral fraction with the established conversion function (Eq. 1) at all sites are shown in Figs. 2, 3, 4, 5, 6 and summarized in Table 1. At incoming sites (Fig. 2), the predicted clay mineral fractions basically show good agreement with the measured ones except for Unit 1A of USB sediments. At the middle part of C0012 (Unit 2-4), the predicted clay mineral fraction is systematically $\sim 5 \%$ lower than the measured ones, though its difference is within the standard deviation for fitting residuals of established conversion function. At toe sites (Fig. 3), the predicted clay mineral fractions for trench wedge sediments at $\mathrm{C0006}$ are in good agreements with the measured ones. At C0024, the predicted clay mineral fractions for trench wedge sediments are systematically higher than the measured ones. This could be due to porosity estimated systematically higher than the MAD porosity at this site. The predicted clay mineral fractions for the accreted USB sediments at toe sites tend to be lower than the measured ones. This deviation of $\sim 10 \%$ is slightly larger than the standard deviation for fitting residuals of established conversion function, though its causes are uncertain. At slope sites (Fig. 4), the predicted clay mineral fractions for slope basin sediments are higher than the measured ones. The same trend can be observed at outer ridge sites (Fig. 5). The predicted clay mineral fractions for slope apron sediments are higher than the measured ones. The predicted clay mineral fractions for other units are consistent with the measured ones except for the inner prism at C0001. This deviation could be due to porosity estimated systematically lower than MAD porosity in this unit. At Kumano Basin sites (Fig. 6), the predicted clay mineral fractions at C0009 agrees with the measured ones, whereas the predicted clay mineral fractions for the inner prism at $\mathrm{C0002}$ is systematically lower than the measured ones possibly due to poor hole condition.

\section{Discussion}

\section{Spectral NGR Log at Site C0009}

NGR logs count gamma ray radiation produced by a geological formation. There are several possible gamma ray radiation sources in geological formations (e.g., Faure 1986). The first is potassium, which is abundant in crustal rocks and exists in various rockforming minerals such as micas, feldspars, and amphiboles. The other two are uranium and thorium, which are usually included in granites, are well absorbed by clay minerals, and can be used as a shale indicator. As we observed correlations between the normalized NGR logs and clay mineral fractions, thorium and uranium are expected to be sources of these NGR log variations. Gamma ray radiation produced by potassium, uranium, and thorium can be discriminated by observing the energy band of the gamma ray radiation. However, the usual NGR log count only accounts for the total amount of gamma ray radiation in the entire energy band. To discriminate between the gamma ray radiation sources, spectral NGR logging is required, although these observations were not commonly performed during the NanTroSEIZE project. Spectral NGR logging was conducted only at site C0009 (Expedition 319 Scientists 2010a).

Figure 8 shows the spectral NGR log data, as well as standard NGR log data. Thorium content fluctuated with depth, which visually correlate well with standard NGR data. Potassium content had peaks around $\sim 900$ and $\sim 950 \mathrm{mbsf}$, though such peaks are not evident in standard NGR logging data. To quantitatively evaluate which component most influenced the standard NGR logging data, we applied multiple regression analyses and calculated the standard partial regression coefficients. The calculated coefficients were -0.69 for potassium, 1.76 for uranium, and 2.53 for thorium, which suggest that the variations in NGR are due to variations in the clay mineral fraction in the formation.

Hüpers et al. (2015) calculated normalized NGR logs for the incoming sites and used them to estimate the abundances of volcanic ash in the Shikoku Basin sediments. Their findings contrast with those of the study, which used normalized NGR logs to estimate the clay mineral fractions. As they focused only on the incoming sites, where the clay mineral fraction was almost constant (60-70\%) (Figs. 2 and 3), variations in the normalized NGR logs are expected to be due to causes other than variations in the clay mineral fraction, such as the presence of volcanic ash. On the other hand, this study used all available data from the Nankai Trough, which spans larger variations in clay mineral fraction, from less than $40 \%$ to more than $70 \%$. When the clay mineral fraction varies so widely, it can be expected 
Table 1 A summary table for all sites studied in this study

\begin{tabular}{|c|c|c|c|c|c|c|c|}
\hline Setting & Site & Unit & $\begin{array}{l}\text { Lithological } \\
\text { interpretation }\end{array}$ & $\begin{array}{l}\text { Normalized } \\
\text { NGR log value } \\
\text { [gAPI] }\end{array}$ & $\begin{array}{l}\text { Predicted } \\
\text { clay } \\
\text { mineral } \\
\text { fraction }\end{array}$ & $\begin{array}{l}\text { Clay mineral } \\
\text { fraction }\end{array}$ & comment \\
\hline \multirow{15}{*}{$\begin{array}{l}\text { Incoming } \\
\text { sites }\end{array}$} & \multirow[t]{6}{*}{$\mathrm{C} 0011$} & $1 \mathrm{~A}$ & USB & $200-220$ & $\sim 0.7-0.8$ & $0.55-0.65$ & High NGR log values due to volcanic ash \\
\hline & & 1B & USB & $\sim 200$ & $\sim 0.7$ & $\sim 0.7$ & \\
\hline & & 2 & MSB & $\begin{array}{l}\text { Scattered }(90- \\
210)\end{array}$ & $\begin{array}{l}\text { Scattered } \\
(0.4-0.7)\end{array}$ & $\begin{array}{l}\text { Scattered } \\
(0.4-0.7)\end{array}$ & Scattered due to interbedding sandy layers \\
\hline & & 3 & LSB & $\sim 200$ & $\sim 0.7$ & $\sim 0.7$ & hemipelagic \\
\hline & & 4 & LSB & $130-220$ & $0.55-0.8$ & \begin{tabular}{|l|} 
Scattered \\
$(0.3-0.75)$ \\
\end{tabular} & $\begin{array}{l}\text { Terrigenous, Scattered due to interbedding sandy } \\
\text { layers }\end{array}$ \\
\hline & & 5 & LSB & $\sim 160$ & $\sim 0.6$ & $\begin{array}{l}\text { Scattered } \\
(0.5-0.9)\end{array}$ & tuff, Scattered due to interbedding sandy layers \\
\hline & \multirow[t]{7}{*}{$\mathrm{C} 0012$} & $1 \mathrm{~A}$ & USB & $190-210$ & $0.65-0.75$ & $0.25-0.65$ & High NGR log values due to volcanic ash \\
\hline & & $1 \mathrm{~B}$ & USB & $\sim 180$ & $\sim 0.65$ & $\sim 0.65$ & \\
\hline & & $1 \mathrm{C}$ & USB & $\sim 180$ & $\sim 0.65$ & $\sim 0.65$ & Rich in volcanic ash \\
\hline & & 2 & MSB & $140-190$ & $0.5-0.7$ & $0.45-0.8$ & Sandy \\
\hline & & 3 & LSB & $\sim 190$ & $\sim 0.7$ & $\sim 0.75$ & hemipelagic \\
\hline & & 4 & LSB & $160-220$ & $0.6-0.8$ & $0.65-0.9$ & terrigenous \\
\hline & & 5 & LSB & $130-190$ & $0.45-0.7$ & \begin{tabular}{|l|} 
Scattered \\
$(0.3-0.9)$ \\
\end{tabular} & $\begin{array}{l}\text { Volcaniclastic, Scattered due to interbedding snady } \\
\text { layer }\end{array}$ \\
\hline & & 6 & Pelagic clay & - & - & - & Too thin to be analyzed \\
\hline & & 7 & Basalt & - & - & - & N/A \\
\hline \multirow[t]{10}{*}{ Toe sites } & \multirow[t]{6}{*}{ C0006 } & 1 & Slope apron & $90-150$ & $0.35-0.55$ & $\sim 0.4$ & Transitional to trench we dge \\
\hline & & $2 \mathrm{~A}$ & Trench wedge & $\sim 110$ & $\sim 0.45$ & $0.3-0.5$ & Sandy \\
\hline & & $2 \mathrm{~B}$ & Trench wedge & $\sim 110$ & $\sim 0.45$ & $0.35-0.6$ & Sandy to muddy \\
\hline & & $2 \mathrm{C}$ & Trench wedge & $\sim 110$ & $\sim 0.45$ & $0.35-0.6$ & muddy \\
\hline & & $2 \mathrm{D}$ & Trench wedge & $\sim 130$ & $\sim 0.5$ & $0.5-0.6$ & Transitional to USB \\
\hline & & 3 & USB & $\sim 150$ & $\sim 0.55$ & $\sim 0.65$ & \\
\hline & \multirow[t]{4}{*}{$\mathrm{CO024}$} & 1 & Slope apron & - & - & - & Too thin to be analyzed \\
\hline & & 2 & Trench & $90-150$ & $0.4-0.55$ & $0.2-0.5$ & There exists bias in porosity estimation \\
\hline & & 3 & Trench & $80-120$ & $0.4-0.5$ & $0.35-0.5$ & Transitional to USB \\
\hline & & 4 & USB & $\sim 130$ & $\sim 0.5$ & $\sim 0.6$ & \\
\hline \multirow[t]{4}{*}{ Slope sites } & \multirow[t]{2}{*}{$\mathrm{C} 0018$} & $1 \mathrm{~A}$ & Slope basin & $\sim 190$ & $\sim 0.65$ & $0.35-0.55$ & High NGR log values due to volcanic ash \\
\hline & & $1 \mathrm{~B}$ & Slope basin & $\sim 160$ & $\sim 0.6$ & $0.3-0.6$ & Sandy, High NGR log values due to volcanic ash \\
\hline & \multirow[t]{2}{*}{$\mathrm{C0021}$} & $1 \mathrm{~A}$ & Slope basin & $180-210$ & $0.65-0.8$ & $0.3-0.5$ & High NGR log values due to volcanic ash \\
\hline & & $1 \mathrm{~B}$ & Slope basin & $\sim 180$ & $\sim 0.65$ & - & Sandy, No clay mineral fraction from core samples \\
\hline \multirow{13}{*}{$\begin{array}{l}\text { Outer } \\
\text { ridge sites }\end{array}$} & \multirow[t]{4}{*}{$\mathrm{C} 0001$} & $1 \mathrm{~A}$ & Slope apron & $140-160$ & $0.5-0.55$ & $0.25-0.5$ & High NGR log values due to volcanic ash \\
\hline & & $1 \mathrm{~B}$ & Slope apron & $\sim 140$ & $\sim 0.5$ & $\sim 0.5$ & High NGR log values due to volcanic ash \\
\hline & & $1 \mathrm{C}$ & Slope apron & $\sim 120$ & $\sim 0.45$ & $\sim 0.35$ & Sandy, High NGR log values due to volcanic ash \\
\hline & & 2 & Inner prism & $\sim 150$ & $\sim 0.55$ & $\sim 0.65$ & \\
\hline & \multirow[t]{5}{*}{$\mathrm{COO04}$} & 1 & Slope apron & $\sim 160$ & $\sim 0.6$ & $0.45-0.55$ & High NGR log values due to volcanic ash \\
\hline & & $2 \mathrm{~A}$ & Inner prism & $\sim 150$ & $\sim 0.55$ & $0.55-0.6$ & Mass transport de posit \\
\hline & & $2 \mathrm{~B}$ & Inner prism & $\sim 150$ & $\sim 0.55$ & $0.55-0.6$ & \\
\hline & & 3 & $\begin{array}{l}\text { Fault bounded } \\
\text { package }\end{array}$ & $\sim 150$ & $\sim 0.55$ & $0.55-0.6$ & \\
\hline & & 4 & $\begin{array}{l}\text { Underthrust } \\
\text { slope apron }\end{array}$ & $\sim 140$ & $\sim 0.5$ & $\sim 0.5$ & \\
\hline & \multirow[t]{2}{*}{$\mathrm{C} 0010$} & 1 & Inner prism & $\sim 190$ & $\sim 0.7$ & $\sim 0.65$ & \\
\hline & & 2 & $\begin{array}{l}\text { Underthrust } \\
\text { slope apron }\end{array}$ & - & - & - & Removed from analysis due to too large depth shift \\
\hline & \multirow[t]{2}{*}{$\mathrm{CO022}$} & $1 \mathrm{~A}$ & Slope apron & $\begin{array}{l}\sim 190 / 120- \\
150\end{array}$ & $\begin{array}{l}0.7 / 0.45- \\
0.6\end{array}$ & \begin{tabular}{|l|}
$0.35-$ \\
$0.55 / 0.4-$ \\
0.55 \\
\end{tabular} & $\begin{array}{l}\text { 0-250 } \mathrm{m} \text { (younger than } \sim 1.5 \mathrm{Ma}) / 250 \mathrm{~m} \text { - (older than } \\
\sim 1.5 \mathrm{Ma} \text { ) }\end{array}$ \\
\hline & & 1B & Slope apron & $\sim 120$ & $\sim 0.45$ & $0.4-0.55$ & Rich in gravel \\
\hline Kumano & $\mathrm{COOO2}$ & 1 & Kumano Basin & $\sim 150$ & $\sim 0.55$ & - & Turbidite, No clay mineral fraction from core samples \\
\hline \multirow[t]{14}{*}{ basin sites } & & 2 & Kumano Basin & $130-150$ & $0.45-0.55$ & $0.4-0.6$ & \\
\hline & & 3 & $\begin{array}{l}\text { Ancient slope } \\
\text { apron }\end{array}$ & $\sim 140$ & $\sim 0.5$ & $0.4-0.6$ & \\
\hline & & $4 \mathrm{~A}$ & Inner prism & $\sim 100$ & $\sim 0.4$ & $0.5-0.65$ & Poor hole condition? \\
\hline & & $4 \mathrm{~B}$ & Inner prism & $\sim 100$ & $\sim 0.4$ & $0.5-0.65$ & Poor hole condition? \\
\hline & & $4 \mathrm{C}$ & Inner prism & $\sim 100$ & $\sim 0.4$ & $0.5-0.65$ & Poor hole condition? \\
\hline & & 4D & Inner prism & $\sim 100$ & $\sim 0.4$ & $0.5-0.65$ & Poor hole condition? \\
\hline & & $4 \mathrm{E}$ & Inner prism & $\sim 100$ & $\sim 0.4$ & $0.5-0.65$ & Poor hole condition? \\
\hline & & $5 \mathrm{~A}$ & Inner prism & $110-140$ & $0.4-0.55$ & $0.5-0.65$ & Poor hole condition? \\
\hline & & $5 \mathrm{~B}$ & Inner prism & $\sim 120$ & 0.45 & $0.5-0.65$ & Poor hole condition? \\
\hline & \multirow[t]{5}{*}{ C0009 } & 1 & Kumano Basin & - & - & - & Turbidite, No clay mineral fraction from core samples \\
\hline & & 2 & Kumano Basin & $\sim 110$ & $\sim 0.45$ & - & No clay mineral fraction from core samples \\
\hline & & $3 \mathrm{~A}$ & $\begin{array}{l}\text { Ancient slope } \\
\text { apron }\end{array}$ & $\sim 130$ & $\sim 0.5$ & - & No clay mineral fraction from core samples \\
\hline & & $3 B$ & $\begin{array}{l}\text { Ancient slope } \\
\text { apron }\end{array}$ & $\sim 110$ & $\sim 0.45$ & $\sim 0.45$ & Rich in organic materials \\
\hline & & 4 & Inner prism & $\sim 130$ & $\sim 0.5$ & $0.5-0.6$ & Poor hole condition? \\
\hline
\end{tabular}



sediments possibly due to volcanic ashes included in sediments. Light blue columns are the inner prism sediment below the Kumano Basin, which shows lower NGR log values than the standard sediments possibly due to poor hole condition. Gray columns are lithological units not used in the analysis
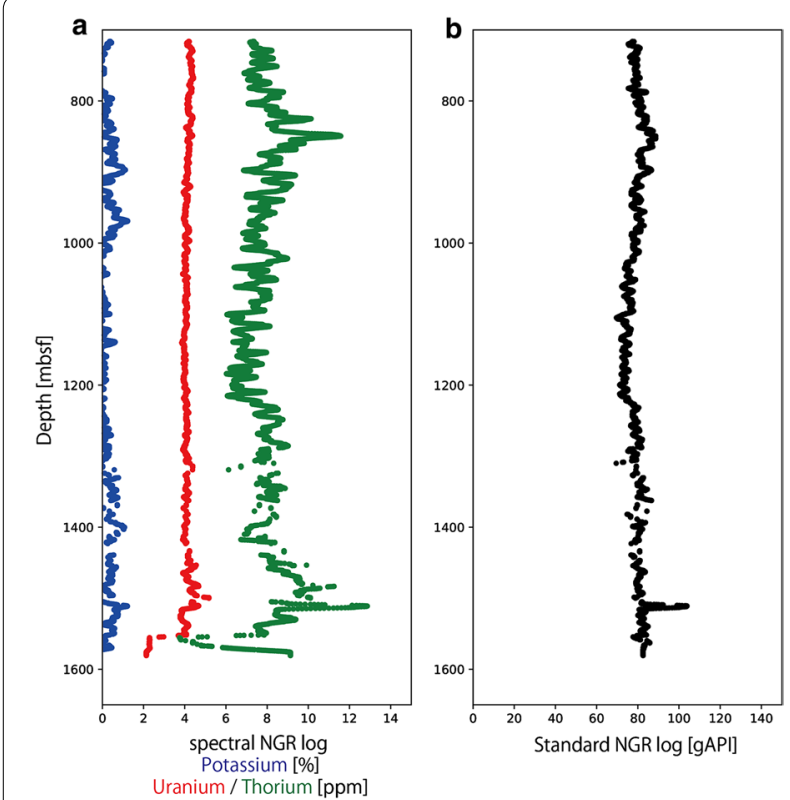

Fig. 8 Gamma Ray log from site C0009. a Results of spectral logging. Blue, red, and green symbols indicate results from potassium, uranium, and thorium. b Standard NGR log

that the normalized NGR logs represent variations in the clay mineral fraction, as NGR logs vary according to thorium and uranium contents (Fig. 8).

\section{Exceptions to the empirical conversion function}

We compiled normalized NGR logs and clay mineral fractions measured from core and cutting samples, and obtained an empirical conversion function between them. However, we excluded several facies that deviated from the main trend when constructing the conversion function (Fig. 7, Additional file 1, 2: S1, and S2). The reason for the deviations can be explained from a sedimentological perspective.

The first exception is Unit 1A of the USB sediments observed at the incoming sites, which exhibits higher normalized NGR values than expected from the other data. Volcanic ash is frequently observed within these strata (Expedition 333 Scientists 2012a, b). Hüpers et al. (2015) also estimated that the volcanic ash fraction of Unit $1 \mathrm{~A}$ is high in the USB sediments. As volcanic ash layers include abundant radioactive elements, this could be a potential cause of the higher normalized NGR values.

The second exception is the slope apron facies, which also exhibit higher normalized NGR values than expected from the other data. Site C0022 (Fig. 5d) clearly contains higher normalized NGR values in the slope apron sediments shallower than $\sim 250$ mbsf, which correspond to ages younger than $\sim 1.5 \mathrm{Ma}$ (Strasser et al. 2014a). This is consistent with the underthrust slope apron sediments observed at site C0004, which are older than $1.5 \mathrm{Ma}$ (Expedition 316 Scientists 2009b) and do not exhibit deviating normalized NGR values (Fig. 5b). According to Strasser et al. (2014a), $250 \mathrm{mbsf}$ at site C0022 does not correspond to a lithologic unit boundary, although a sub-unit boundary in $\log$ unit is documented at $\sim 213$ mbsf. This depth may correlate with temporal changes in the riverine sediment supply. According to Usman et al. (2014), the Kumano Basin sediments and slope apron sediments were originally supplied by the Kumano River on the Kii Peninsula and the Tenryu River in the Tokai region. At $\sim 1 \mathrm{Ma}$, megasplay fault activity uplifted the outer ridge (Strasser et al. 2009; Moore et al. 2015a, b) and cut off the sediment supply from the Kumano River to the slope apron. At this time, the sediment supply from the Fuji River to the trench axial current became dominant. Sediments from the Izu-Honshu collision zone supplied by the Fuji River are rich in volcanic materials (Usman et al. 2014), resulting in higher normalized NGR values. However, this hypothesis contradicts the normal NGR values observed in the trench wedge sediments at the toe sites. In contrast, Clift et al. (2013) suggested that the influence of the Fuji River on the trench wedge sediments is weak, even along the Kumano section. Further studies are, therefore, needed to resolve these contradictory findings.

The last exception is the inner prism sediments below the Kumano Basin at site $\mathrm{C0002}$, which exhibit lower normalized NGR values than expected. As discussed in "Normalized gamma ray logs vs. clay mineral fractions" section, this could be due to poor hole conditions at this site, because this deviation is less evident at sites C0001 and C0009. However, it might also be due to different sediment sources. Underwood (2018) suggested that the inner prism sediments are supplied not from the PSP, but from the Pacific Plate, based on analyses of the clay mineral assemblages. If the sediment origin is completely 

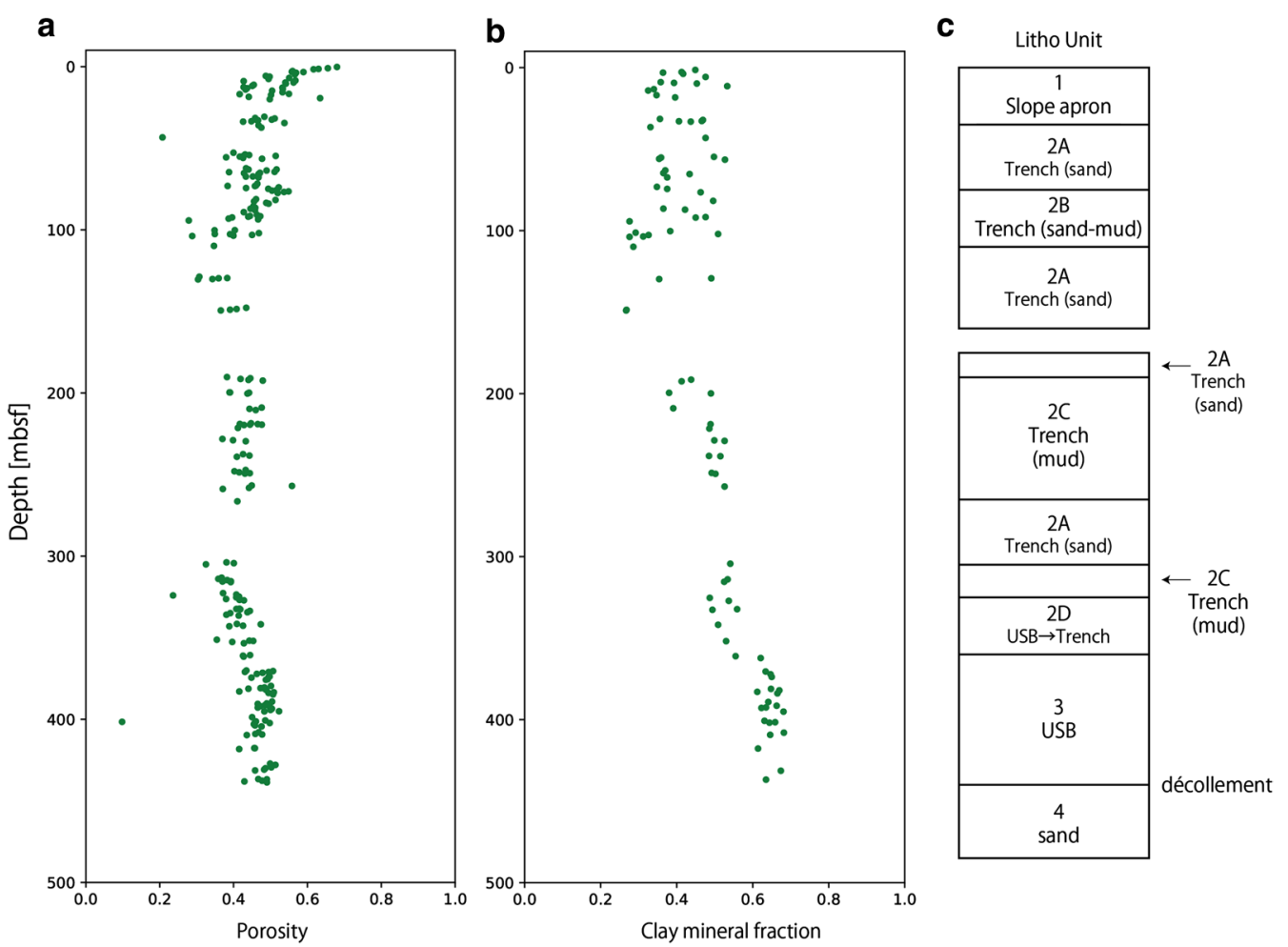

Fig. 9 Data from site C0007. Depth profiles of $\mathbf{a}$ porosity and $\mathbf{b}$ clay mineral fraction measured from core samples are shown. Lithologic unit descriptions are also shown in c

different from that of the Shikoku Basin sediments, the empirical conversion function established herein cannot be applied to the inner prism sediments below the Kumano Basin sediments.

When applying our new method in future drillings, it is possible to expect whether the predicted clay mineral fraction deviates from the actual values by monitoring borehole conditions and knowing which layer is drilled through using information from seismic surveys. Although comparisons with the clay mineral fraction measured for core samples are required to validate the predicted values, dense measurements, as has been done during NanTroSEIZE project, are not needed saving the effort of onboard scientists.

\section{Lithological interpretations without core samples}

The empirical conversion function determined in this study provides estimations of clay mineral fractions at depths, where both electrical resistivity logs and NGR logs are available. Using this new conversion method, it is possible to interpret the subsurface lithology, even when core samples are not recovered or when the clay mineral fraction is not measured directly.

At the incoming sites, MSB or Zenisu Fan sediments are observed as sandy turbidite facies (Expedition 322
Scientists 2010a, b; Expedition 333 Scientists 2012a, b; Pickering et al. 2013). However, the clay mineral fractions measured from the core samples are around 70\% (Fig. 2), which does not correspond to the visual core descriptions. In contrast, the clay mineral fractions estimated from the logging data exhibit low values of $\sim 40 \%$ at site C0011 and $\sim 50 \%$ at site C0012. In addition, the clay mineral fraction is not uniform; rather, there are several sandy layers interbedded in the clayey sediments, which is consistent with the visual core descriptions (Expedition 322 Scientists 2010a, b; Expedition 333 Scientists 2012a, b; Pickering et al. 2013). Therefore, the clay mineral fractions estimated from the logging data more accurately reflect the characteristics of the bulk rock in the borehole.

At the toe sites, the shallow décollement was drilled at sites C0006, C0007, and C0024 (Expedition 314 Scientists 2009b; Expedition 316 Scientists 2009a, c; Yamaguchi et al. 2020). Unfortunately, site $\mathrm{C} 0007$ was only cored, whereas the shallow décollement at sites C0006 and C0024 were only logged with LWD (Fig. 2). At site C0007, the underthrust layer below the décollement is sandy sediments, based on visual core descriptions (Expedition 316 Scientists 2009a), although the clay mineral fraction was not measured in this layer due to very low core recovery 
(Fig. 9). The clay mineral fraction of the underthrust layer is estimated to be $30 \%$ from the logging data collected at site C0006 (Fig. 2). This value is consistent with the lowest values of clay mineral fraction measured in the trench wedge sediment (Unit 2 of $\mathrm{C0006}$ and C0024). In contrast, this low clay mineral fraction is not estimated at site C0024 (Fig. 2), which suggests that the hole did not penetrate the underthrust sandy layer. The clay mineral fraction estimated from the logging data also provides a detailed depth profile around the shallow décollement, which is difficult to observe using core sample measurements. Such information is important for understanding the structural geology to consider the controls on the location of the shallow décollement.

\section{Conclusions}

Determining sediment lithologies, especially the clay mineral fraction, in accretionary prisms is important, because it is essential information that can be used for a variety of geological studies. The clay mineral fraction is usually measured using cores acquired during drilling. The sand-clay ratio is also qualitatively evaluated using NGR logs, because radioactive thorium and uranium tend to concentrate in the clay minerals. However, NGR logs have not been quantitatively related to the clay mineral fraction, because the concentrations of radioactive elements are strongly dependent on lithology. This study focused on the Nankai Trough and established an empirical conversion function from the NGR logs to the clay mineral fraction of the sediment.

In this new method, NGR logs compensated for the influence of porosity were empirically converted into the clay mineral fractions. Porosities were estimated from the electrical resistivity logs using the method of Yabe et al. (2019). As a byproduct of the porosity estimations, estimations of thermal conductivity and temperature depth profiles were obtained at all NanTroSEIZE drilling sites, where logging data are available. To establish the empirical conversion function, NGR logs compensated for the influence of porosity were compared with the clay mineral fractions measured from core samples. We found a linear relationship between these two values, with some exceptions. The exceptions were due to high concentrations of volcanic ash in the slope apron facies younger than $\sim 1.5 \mathrm{Ma}$ and in Unit $1 \mathrm{~A}$ of the USB sediments. The empirical conversion function established in this study is for the Nankai trough, though our method is applicable to other subduction zones if enough log data and clay fraction data are available.

This new method and its results are useful in various ways to understand seismogenesis and evolutionary process of the shallow accretionary prism. For example, when deviations are observed between core sample measurements and estimations using the new method, irregular components are present in the sediments, which is important for determining the sedimentology. Continuously measured logging data provide a more detailed depth profile of the clay mineral fraction than discrete core sample measurements. Such a detailed profile is important for interpreting the subsurface structural geology. As electrical resistivity logs and NGR logs are essential measurements conducted during downhole logging, this new method can easily be applied to future scientific drilling expeditions in the Nankai Trough.

\section{Supplementary information}

Supplementary information accompanies this paper at https://doi. org/10.1186/s40623-020-01303-1.

Additional file 1: Figure S1. Same as Fig. 7, but using the NGR logs normalized using MAD porosity values.

Additional file 2: Figure S2. Same as Fig. 7, but using the NGR logs normalized using porosities estimated from the density logs.

\section{Abbreviations}

BSR: Bottom simulating reflector; IODP: International Ocean Discovery Project; LWD: Logging while drilling; MAD: Moisture and density; NGR: Natural gamma radiation; PSP: Philippine Sea Plate; USB/MSB/LSB: Upper/Middle/Lower Shikoku Basin; XRD: X-ray diffraction.

\section{Acknowledgements}

This study was made possible by participating in the IODP workshop "CoreLog-Seismic Integration at Sea" and IODP Expedition 358 on D/V Chikyu. The authors appreciate the shipboard assistance of the Marine Works Japan laboratory technicians, as well as Mantle Quest Japan Ltd. for operating D/N Chikyu. We thank Prof. Kyuichi Kanagawa, Drs. Takehiro Hirose, Manami Kitamura, and Yoshinori Sanada for their helpful comments on this manuscript. Some of the figures were produced using the GMT software package (Wessel et al. 2013).

\section{Authors' contributions}

All authors contributed toward the conception of this study. SY analyzed data and drafted the manuscript. All authors contributed to the revision of the manuscript. All authors read and approved the final manuscript.

\section{Funding}

This research was supported by the Japan Society for Promotion of Science KAKENHI (Grant Number JP15H05717). This research was also supported by the management expenses of the Japan Agency for Marine-Earth Science and Technology (JAMSTEC) and the National Institute of Advanced Industrial Science and Technology (AIST).

\section{Availability of data and materials}

The datasets supporting the conclusions of this article are available at http:// sio7.jamstec.go.jp. Figures of seismic profiles shown in Figs. 1, 2, 3, 4, 5, 6 are available at https://iodp.tamu.edu under CC by 4.0 license.

\section{Consent for publication}

Not applicable.

\section{Competing interests}

The authors declare that they have no competing interests.

\section{Author details}

${ }^{1}$ Geological Survey of Japan, National Institute of Advanced Industrial Science and Technology (AIST), Tsukuba Central 7, 1-1-1 Higashi, Tsukuba, Ibaraki 305-8567, Japan. ${ }^{2}$ Geoengineering Headquarters, Dia Consultants Co., Ltd., 
2-272-3 Yoshino-cho, Kita-ku, Saitama 331-0811, Japan. ${ }^{3}$ Institute for Extracutting-edge Science and Technology Avant-garde Research, Kochi Institute for Core Sample Research, Japan Agency for Marine-Earth Science and Technology, 200 Monobe Otsu, Nankoku-shi, Kochi 783-8502, Japan. ${ }^{4}$ Department of Marine Environment and Resources, Tokyo University of Marine Science and Technology, No. 2 Building 311, 4-5-7 Konan, Minato-ku, Tokyo 108-8477, Japan.

Received: 11 August 2020 Accepted: 22 October 2020 Published online: 31 October 2020

\section{References}

Archie GE (1942) The electrical resistivity log as an aid in determining some reservoir characteristics, JPT. J Pet Technol 5:1-8

Clift PD, Carter A, Nicholson U, Masago H (2013) Zircon and apatite thermochronology of the Nankai Trough accretionary prism and trench, Japan: Sediment transport in an active and collisional margin setting. Tectonics 32:377-395. https://doi.org/10.1002/tect.20033

DeMets C, Gordon RG, Argus DF (2010) Geologically current plate motion. Geophys J Int 181(1):1-80. https://doi.org/10.1111/j.1365246X.2009.04491.x

Expedition 314 Scientists (2009a) Expedition 314 methods. In: Kinoshita M Tobin H, Ashi J, Kimura G, Lallement S, Screaton EJ, Curewitz D, Masago H, Moe KT, and the Expedition 314/315/316 Scientists, Proc. IODP, 314/315/316: Washington, DC (Integrated Ocean Drilling Program Management International, Inc.). https://doi.org/10.2204/iodp.proc.31431 5316.112 .2009

Expedition 314 Scientists (2009b) Expedition 314 Site C0006. In: Kinoshita M, Tobin H, Ashi J, Kimura G, Lallemant S, Screaton EJ, Curewitz D, Masago H, Moe KT, and the Expedition 314/315/316 Scientists, Proc. IODP, 314/315/316: Washington, DC (Integrated Ocean Drilling Program Management International, Inc.). https://doi.org/10.2204/iodp.proc.31431 5316.118 .2009

Expedition 314 Scientists (2009c) Expedition 314 Site C0001. In: Kinoshita M, Tobin H, Ashi J, Kimura G, Lallement S, Screaton EJ, Curewitz D, Masago H, Moe KT, and the Expedition 314/315/316 Scientists, Proc. IODP, 314/315/316: Washington, DC (Integrated Ocean Drilling Program Management International, Inc.). https://doi.org/10.2204/iodp.proc.31431 5316.113.2009

Expedition 314 Scientists (2009d) Expedition 314 Site C0004. In: Kinoshita M, Tobin H, Ashi J, Kimura G, Lallement S, Screaton EJ, Curewitz D, Masago H, Moe KT, and the Expedition 314/315/316 Scientists, Proc. IODP, 314/315/316: Washington, DC (Integrated Ocean Drilling Program Management International, Inc.). https://doi.org/10.2204/iodp.proc.31431 5316.116 .2009

Expedition 314 Scientists (2009e). Expedition 314 Site C0002. In: Kinoshita M, Tobin H, Ashi J, Kimura G, Lallement S, Screaton EJ, Curewitz D, Masago H, Moe KT, and the Expedition 314/315/316 Scientists, Proc IODP, 314/315/316: Washington, DC (Integrated Ocean Drilling Program Management International, Inc.). https://doi.org/10.2204/iodp.proc.31431 5316.114 .2009

Expedition 315 Scientists (2009a) Expedition 315 methods. In: Kinoshita M, Tobin H, Ashi J, Kimura G, Lallemant S, Screaton EJ, Curewitz D, Masago H, Moe KT, and the Expedition 314/315/316 Scientists, Proc. IODP, 314/315/316: Washington, DC (Integrated Ocean Drilling Program Management International, Inc.). https://doi.org/10.2204/iodp.proc.31431 5316.122 .2009

Expedition 315 Scientists (2009b) Expedition 315 Site C0001. In: Kinoshita M, Tobin H, Ashi J, Kimura G, Lallemant S, Screaton EJ, Curewitz D, Masago H, Moe KT, and the Expedition 314/315/316 Scientists, Proc. IODP, 314/315/316: Washington, DC (Integrated Ocean Drilling Program Management International, Inc.). https://doi.org/10.2204/iodp.proc.31431 5316.123.2009

Expedition 315 Scientists (2009c). Expedition 315 Site C0002. In: Kinoshita M, Tobin H, Ashi J, Kimura G, Lallemant S, Screaton EJ, Curewitz D, Masago H, Moe KT, and the Expedition 314/315/316 Scientists, Proc IODP, 314/315/316: Washington, DC (Integrated Ocean Drilling Program Management International, Inc.). https://doi.org/10.2204/iodp.proc.31431 5316.124.2009
Expedition 316 Scientists (2009a) Expedition 316 Site C0006. In: Kinoshita M, Tobin H, Ashi J, Kimura G, Lallemant S, Screaton EJ, Curewitz D, Masago H, Moe KT, and the Expedition 314/315/316 Scientists, Proc. IODP, 314/315/316: Washington, DC (Integrated Ocean Drilling Program Management International, Inc.). https://doi.org/10.2204/iodp.proc.31431 5316.134.2009

Expedition 316 Scientists (2009b) Expedition 316 Site C0004. In: Kinoshita M, Tobin H, Ashi J, Kimura G, Lallemant S, Screaton EJ, Curewitz D, Masago $\mathrm{H}$, Moe KT, and the Expedition 314/315/316 Scientists, Proc. IODP, 314/315/316: Washington, DC (Integrated Ocean Drilling Program Management International, Inc.). https://doi.org/10.2204/iodp.proc.31431 5316.133 .2009

Expedition 316 Scientists (2009c) Expedition 316 Site C0007. In: Kinoshita M, Tobin H, Ashi J, Kimura G, Lallemant S, Screaton EJ, Curewitz D, Masago H, Moe KT, and the Expedition 314/315/316 Scientists, Proc. IODP, 314/315/316: Washington, DC (Integrated Ocean Drilling Program Management International, Inc.). https://doi.org/10.2204/iodp.proc.31431 5316.135 .2009

Expedition 319 Scientists (2010a) Site C0009. In: Saffer D, McNeill L, Byrne T, Araki E, Toczko S, Eguchi N, Takahashi K, and the Expedition 319 Scientists, Proc. IODP, 319: Tokyo (Integrated Ocean Drilling Program Management International, Inc.). https://doi.org/10.2204/iodp.proc.319.103.2010

Expedition 319 Scientists (2010b) Methods. In: Saffer D, McNeill L, Byrne T, Araki E, Toczko S, Eguchi N, Takahashi K, and the Expedition 319 Scientists, Proc. IODP, 319: Tokyo (Integrated Ocean Drilling Program Management International, Inc.). https://doi.org/10.2204/iodp.proc.319.102.2010

Expedition 319 Scientists (2010c) Site C0010. In: Saffer D, McNeill L, Byrne T, Araki E, Toczko S, Eguchi N, Takahashi K, and the Expedition 319 Scientists, Proc. IODP, 319: Tokyo (Integrated Ocean Drilling Program Management International, Inc.). https://doi.org/10.2204/iodp.proc.319.104.2010

Expedition 322 Scientists (2010a) Site C0011. In: Saito S, Underwood MB, Kubo Y, and the Expedition 322 Scientists, Proc. IODP, 322: Tokyo (Integrated Ocean Drilling Program Management International, Inc.). https://doi. org/10.2204/iodp.proc.322.103.2010

Expedition 322 Scientists (2010b) Site C0012. In: Saito S, Underwood MB, Kubo Y, and the Expedition 322 Scientists, Proc. IODP, 322: Tokyo (Integrated Ocean Drilling Program Management International, Inc.). https://doi. org/10.2204/iodp.proc.322.104.2010

Expedition 333 Scientists (2012a) Site C0011. In: Henry, P., Kanamatsu, T., Moe, K., and the Expedition 333 Scientists, Proc. IODP, 333: Tokyo (Integrated Ocean Drilling Program Management International, Inc.). https://doi. org/10.2204/iodp.proc.333.104.2012

Expedition 333 Scientists (2012b) Site C0012. In: Henry P, Kanamatsu T, Moe K, and the Expedition 333 Scientists, Proc. IODP, 333: Tokyo (Integrated Ocean Drilling Program Management International, Inc.). https://doi. org/10.2204/iodp.proc.333.105.2012

Expedition 333 Scientists (2012c) Site C0018. In: Henry P, Kanamatsu T, Moe K, and the Expedition 333 Scientists, Proc. IODP, 333: Tokyo (Integrated Ocean Drilling Program Management International, Inc.). https://doi. org/10.2204/iodp.proc.333.103.2012

Faure G (1986). Principles of Isotope Geology, second ed. Wiley, (ISBN: 0471864129)

Guo J, Underwood MB (2012) Data report: clay mineral assemblages from the Nankai Trough accretionary prism and the Kumano Basin, IODP Expeditions 315 and 316, NanTroSEIZE Stage 1. In: Kinoshita M, Tobin H, Ashi J, Kimura G, Lallemant S, Screaton EJ, Curewitz D, Masago H, Moe KT, and the Expedition 314/315/316 Scientists, Proc. IODP, 314/315/316: Washington, DC (Integrated Ocean Drilling Program Management International, Inc.). https://doi.org/10.2204/iodp.proc.314315316.202.2012

Hampson GJ, Davies W, Davies SJ, Howell JA, Adamson KR (2005) Use of spectral gamma-ray data to refine subsurface fluvial stratigraphy: late Cretaceous strata in the Book Cliffs, Utah, USA. J Geol Soc 162(4):603-621. https://doi.org/10.1144/0016-764904-059

Harris RN, Schmidt-Schierhorn F, Spinelli G (2011) Heat flow along the NanTroSEIZE transect: Results from IODP Expeditions 315 and 316 offshore of the Kii Peninsula, Japan, Geochem Geophys Geosyst 12, Q0AD16. https://doi. org/10.1029/2011gc003593

Hüpers A, Ikari MJ, Underwood MB, Kopf AJ (2015) Origin of a zone of anomalously high porosity in the subduction inputs to Nankai Trough. Mar Geol 361:147-162. https://doi.org/10.1016/j.margeo.2015.01.004 
Hüpers A, Torres ME, Owari S, McNeill LC, Dugan B, HenstockTJ, Milliken KL, Petronotis KE, Backman J, Bourlange S, Chemale F, Chen W, Colson TA, Frederik MCG, Guèrin G, Hamahashi M, House BM, Jeppson TN, Kachovich S, Kenigsberg AR, Kuranaga M, Kutterolf S, Mitchison FL, Mukoyoshi H, Nair N, Pickering KT, Pouderoux HFA, Shan Y, Song I, Vannucchi P, Vrolijk PJ, Yang T, Zhao X (2017) Release of mineral-bound water prior to subduction tied to shallow seismogenic slip off Sumatra. Science 356(6340):841844. https://doi.org/10.1126/science.aal3429

Ishii T, Sato H, Machida S, Haraguchi S, Usui A, Ishizuka O, Taniguchi H, Yagi K (2000) Geological and petrological studies of the Kinan and Izu-Ogasawara back arc enchelon seamount chains. Bull Geol Surv Jpn 51:615-630

Ishizuka O, Taylor RN, Yuasa M, Ohara Y (2011) Making and breaking an island arc: a new perspective from the Oligocene Kyushu-Palau arc, Philippine Sea. Geochem Geophys Geosyst 12:Q05005. https://doi. org/10.1029/2010GC003440

Kimura G, Kitamura Y, Hashimoto Y, Yamaguchi A, Shibata T, Ujiie K, Okamoto S (2007) Transition of accretionary wedge structures around the up-dip limit of the seismogenic subduction zone. Earth Planet Sci Lett 255:471-484. https://doi.org/10.1016/j.epsl.2007.01.005

Kimura G, Moore GF, Strasser M, Screaton E, Curewitz D, Streiff C, Tobin H (2011) Spatial and temporal evolution of the megasplay fault in the Nankai Trough. Geochem Geophys Geosyst. https://doi.org/10.1029/2010g c003335

Kimura G, Koge H, Tsuji T (2018) Punctuated growth of an accretionary prism and the onset of a seismogenic megathrust in the Nankai Trough. Progr Earth Planet Sci 5:78. https://doi.org/10.1186/s40645-018-0234-1

Kitajima H, Hirose T, Ikari M, Kanagawa K, Kimura G, Kinoshita M, Saffer D, Tobin H, Yamaguchi A, Eguchi N, Maeda L, Toczko S, Bedford J, Chiyonobu S, Colson TA, Conin M, Cornard PH, Dielforder A, Doan M-L, Dutilleul J, Faulkner DR, Fukuchi R, Guérin G, Hamada Y, Hamahashi M, Hong W-L, Ijiri A, Jaeger D, Jeppson T, Jin Z, John BE, Kitamura M, Kopf A, Masuda H, Matsuoka A, Moore GF, Otsubo M, Regalla C, Sakaguchi A, Sample J, Schleicher A, Sone H, Stanislowski K, Strasser M, Toki T, Tsuji T, Ujiie K, Underwood MB, Yabe S, Yamamoto Y, Zhang J, Sanada Y, Kido Y, Le Ber E, Saito S (2020) Site C0002. With contributions from T. Kanamatsu. In: Tobin H, Hirose T, Ikari M, Kanagawa K, Kimura G, Kinoshita M, Kitajima H, Saffer D, Yamaguchi A, Eguchi N, Maeda L, Toczko S, and Expedition 358 Scientists, NanTroSEIZE Plate Boundary Deep Riser 4: Nankai Seismogenic/Slow Slip Megathrust. In: Proceedings of the International Ocean Discovery Program, 358: College Station, TX (International Ocean Discovery Program). https://doi.org/10.14379/iodp.proc.358.103.2020

Miyazaki S, Heki K (2001) Crustal velocity field of southwest Japan: subduction and arc-arc collision. J Geophys Res 106:4305-4326. https://doi. org/10.1029/2000JB900312

Moore GF, Shipley TH (1988) Mechanisms of sediment accretion in the Middle America Trench off Mexico. J Geophys Res 93:8911-8927

Moore JC, Roeske SM, Lundberg N, Schoonmaker J, Cowan DS, Gonzales E, Lucas SE (1986) Scaly fabrics from the deep sea drilling project cores from forearcs. In: Moore JC (Ed.), Structural Fabric in Deep Sea Drilling Project Cores from Forearcs: Mem. Geol. Soc. Am., 166, pp 55-73

Moore GF, Shipley TH, Stoffa PL, Karig DE, Taira A, Kuramoto S, Tokuyama H, Suyehiro K (1990) Structure of the Nankai Trough accretionary zone from multichannel seismic reflection data. J Geophys Res 95:8753-8765

Moore GF, Boston BB, Strasser M, Underwood MB, Ratliff RA (2015a) Evolution of tectono-sedimentary systems in the Kumano Basin, Nankai Trough forearc. Mar Petrol Geol 67:604-616. https://doi.org/10.1016/j.marpe tgeo.2015.05.032

Moore JC, Plank TA, Chester FM, Polissar PJ, Savage HM (2015b) Sediment provenance and controls on slip propagation: lessons learned from the 2011 Tohoku and other great earthquakes of the subducting northwest Pacific Plate. Geosphere 11(3):533-541

Ohde A, Otsuka H, Kioka A, Ashi J (2018) Distribution and depth of bottomsimulating reflectors in the Nankai subduction margin. Earth Planets Space 70:60. https://doi.org/10.1186/s40623-018-0833-5

Okino K, Shimakawa Y, Nagaoka S (1994) Evolution of the Shikoku Basin. J Geomagn Geoelectr 46:463-479. https://doi.org/10.5636/jgg.46.463

Okino K, Ohara Y, Kasuga S, Kato Y (1999) The Philippine Sea: new survey results reveal the structure and history of the marginal basins. Geophys Res Lett 26:2287-2290. https://doi.org/10.1029/1999GL900537

Oohashi K, Hirose T, Takahashi M, Tanikawa W (2015) Dynamic weakening of smectite-bearing faults at intermediate velocities: implications for subduction zone earthquakes. J. Geophys. Res. Solid Earth 120:15721586. https://doi.org/10.1002/2015JB011881

Pickering KT, Underwood MB, Saito S, Naruse H, Kutterolf S, Scudder R, Park J-O, Moore GF, Slagle A (2013) Depositional architecture, provenance, and tectonic/eustatic modulation of Miocene submarine fans in the Shikoku Basin: results from the Nankai Trough Seismogenic Zone Experiment. Geochem Geophys Geosyst 14:1722-1739. https://doi.org/10.1002/ ggge.20107

Saffer D, Kopf A, Toczko S, Araki E, Carr S, Kimura T, Kinoshita C, Kobayashi R, Machida Y, Rösner A, Wallace LM (2017) Site C0010. With contributions from Chiyonobu S, Kanagawa K, Kanamatsu T, Kimura G, Underwood MB. In: Saffer D, Kopf A, Toczko S, and Expedition 365 Scientists, NanTroSEIZE Stage 3: Shallow Megasplay Long-Term Borehole Monitoring System. Proceedings of the International Ocean Discovery Program, 365: College Station, TX (International Ocean Discovery Program). https://doi. org/10.14379/iodp.proc.365.103.2017

Sawai M, Hirose T, Kameda J (2014) Frictional properties of incoming pelagic sediments at the Japan Trench: implications for large slip at a shallow plate boundary during the 2011 Tohoku earthquake. Earth Planets Space 66:65. https://doi.org/10.1186/1880-5981-66-65

Sdrolias M, Roest WR, Müller RD (2004) An expression of Philippine Sea plate rotation: the Parece Vela and Shikoku Basins. Tectonophysics 394:69-86. https://doi.org/10.1016/j.tecto.2004.07.061

Strasser M, Moore GF, Kimura G, Kitamura Y, Kopf AJ, Lallemant S, Park J-O, Screaton EJ, Su X, Underwood MB (2009) Origin and evolution of a splay fault in the Nankai accretionary wedge. Nat Geosci 2:648-652. https://doi. org/10.1038/ngeo609

Strasser M, Dugan B, Kanagawa K, Moore GF, Toczko S, Maeda L, Kido Y, Moe KT, Sanada Y, Esteban L, Fabbri O, Geersen J, Hammerschmidt S, Hayashi H, Heirman K, Hüpers A, Jurado Rodriguez MJ, Kameo K, Kanamatsu T, Kitajima H, Masuda H, Milliken K, Mishra R, Motoyama I, Olcott K, Oohashi K, Pickering KT, Ramirez SG, Rashid H, Sawyer D, Schleicher A, Shan Y, Skarbek R, Song I, Takeshita T, Toki T, Tudge J, Webb S, Wilson DJ, Wu H-Y, Yamaguchi A (2014a) Site C0022. In Strasser M, Dugan B, Kanagawa K, Moore GF, Toczko S, Maeda L, and Expedition 338 Scientists, Proc. IODP, 338: Yokohama (Integrated Ocean Drilling Program). https://doi. org/10.2204/iodp.proc.338.107.2014

Strasser M, Dugan B, Kanagawa K, Moore GF, Toczko S, Maeda L, Kido Y, Moe KT, Sanada Y, Esteban L, Fabbri O, Geersen J, Hammerschmidt S, Hayashi H, Heirman K, Hüpers A, Jurado Rodriguez MJ, Kameo K, Kanamatsu T, Kitajima H, Masuda H, Milliken K, Mishra R, Motoyama I, Olcott K, Oohashi K, Pickering KT, Ramirez SG, Rashid H, Sawyer D, Schleicher A, Shan Y, Skarbek R, Song I, Takeshita T, Toki T, Tudge J, Webb S, Wilson DJ, Wu H-Y, Yamaguchi A (2014b). Site C0012. In', Proc. IODP, 338: Yokohama (Integrated Ocean Drilling Program). https://doi.org/10.2204/iodp. proc.338.104.2014

Strasser M, Dugan B, Kanagawa K, Moore GF, Toczko S, Maeda L, Kido Y, Moe KT, Sanada Y, Esteban L, Fabbri O, Geersen J, Hammerschmidt S, Hayashi H, Heirman K, Hüpers A, Jurado Rodriguez MJ, Kameo K, Kanamatsu T, Kitajima H, Masuda H, Milliken K, Mishra R, Motoyama I, Olcott K, Oohashi K, Pickering KT, Ramirez SG, Rashid H, Sawyer D, Schleicher A, Shan Y, Skarbek R, Song I, Takeshita T, Toki T, Tudge J, Webb S, Wilson DJ, Wu H-Y, Yamaguchi A (2014c) Site C0018. In: Strasser M, Dugan B, Kanagawa K, Moore GF, Toczko S, Maeda L, and Expedition 338 Scientists, Proc. IODP, 338: Yokohama (Integrated Ocean Drilling Program). https://doi. org/10.2204/iodp.proc.338.105.2014

Strasser M, Dugan B, Kanagawa K, Moore GF, Toczko S, Maeda L, Kido Y, Moe KT, Sanada Y, Esteban L, Fabbri O, Geersen J, Hammerschmidt S, Hayashi H, Heirman K, Hüpers A, Jurado Rodriguez MJ, Kameo K, Kanamatsu T, Kitajima H, Masuda H, Milliken K, Mishra R, Motoyama I, Olcott K, Oohashi K, Pickering KT, Ramirez SG, Rashid H, Sawyer D, Schleicher A, Shan Y, Skarbek R, Song I, Takeshita T, Toki T, Tudge J, Webb S, Wilson DJ, Wu H-Y, Yamaguchi A (2014d) Site C0021. In: Strasser M, Dugan B, Kanagawa K, Moore GF, Toczko S, Maeda L, and Expedition 338 Scientists, Proc. IODP, 338: Yokohama (Integrated Ocean Drilling Program). https://doi. org/10.2204/iodp.proc.338.106.2014

Strasser M, Dugan B, Kanagawa K, Moore GF, Toczko S, Maeda L, Kido Y, Moe KT, Sanada Y, Esteban L, Fabbri O, Geersen J, Hammerschmidt S, Hayashi H, Heirman K, Hüpers A, Jurado Rodriguez MJ, Kameo K, Kanamatsu T, Kitajima H, Masuda H, Milliken K, Mishra R, Motoyama I, Olcott K, Oohashi K, Pickering KT, Ramirez SG, Rashid H, Sawyer D, Schleicher A, Shan Y, 
Skarbek R, Song I, Takeshita T, Toki T, Tudge J, Webb S, Wilson DJ, Wu H-Y, Yamaguchi A (2014e) Site C0002. In: Strasser M, Dugan B, Kanagawa K, Moore GF, Toczko S, Maeda L, and Expedition 338 Scientists, Proc. IODP, 338: Yokohama (Integrated Ocean Drilling Program). https://doi. org/10.2204/iodp.proc.338.103.2014

Sugihara T, Kinoshita M, Araki E, Kimura T, Kyo M, Namba Y, Kido Y, Sanada Y, Thu M (2014) Reevaluation of temperature at the updip limit of locked portion of Nankai megasplay inferred from IODP Site C0002 temperature observatory. Earth, Planets and Space 66:107. https://doi. org/10.1186/1880-5981-66-107

Tobin HJ, Kinoshita M (2006) NanTroSEIZE: the IODP Nankai Trough seismogenic zone experiment. Sci Drill 2:23-27. https://doi.org/10.2204/iodp. sd.2.06.2006

Tobin H, Kinoshita M, Moe KT, and the Expedition 314 Scientists (2009). Expedition 314 summary. In Kinoshita M, Tobin H, Ashi J, Kimura G, Lallemant S, Screaton EJ, Curewitz D, Masago H, Moe KT, and the Expedition 314/315/316 Scientists, Proc. IODP, 314/315/316: Washington, DC (Integrated Ocean Drilling Program Management International, Inc.). https:// doi.org/10.2204/iodp.proc.314315316.111.2009

Tobin H, Hirose T, Saffer D, Toczko S, Maeda L, Kubo Y, Boston B, Broderick A, Brown K, Crespo-Blanc A, Even E, Fuchida S, Fukuchi R, Hammerschmidt S, Henry P, Josh M, Jurado MJ, Kitajima H, Kitamura M, Maia A, Otsubo M, Sample J, Schleicher A, Sone H, Song C, Valdez R, Yamamoto Y, Yang K, Sanada Y, Kido Y, Hamada Y (2015a) Site C0002. In Tobin H, Hirose T, Saffer D, Toczko S, Maeda L, Kubo Y, and Expedition 348 Scientists, Proc. IODP, 348: College Station, TX (Integrated Ocean Drilling Program). https://doi. org/10.2204/iodp.proc.348.103.2015

Tobin H, Hirose T, Saffer D, Toczko S, Maeda L, Kubo Y, Boston B, Broderick A, Brown K, Crespo-Blanc A, Even E, Fuchida S, Fukuchi R, Hammerschmidt S, Henry P, Josh M, Jurado MJ, Kitajima H, Kitamura M, Maia A, Otsubo M, Sample J, Schleicher A, Sone H, Song C, Valdez R, Yamamoto Y, Yang K, Sanada Y, Kido Y, Hamada Y (2015b) Methods. In: Tobin H, Hirose T, Saffer D, Toczko S, Maeda L, Kubo Y, and Expedition 348 Scientists, Proc. IODP, 348: College Station, TX (Integrated Ocean Drilling Program). https://doi. org/10.2204/iodp.proc.348.102.2015

Tobin H, Hirose T, Ikari M, Kanagawa K, Kimura G, Kinoshita M, Kitajima H, Saffer, D Yamaguchi A, Eguchi N, Maeda L, Toczko S, Bedford J, Chiyonobu S, Colson TA, Conin M, Cornard PH, Dielforder A, Doan M-L, Dutilleul J, Faulkner DR, Fukuchi R, Guérin G, Hamada Y, Hamahashi M, Hong W-L, Ijiri A, Jaeger D, Jeppson T, Jin Z, John BE, Kitamura M, Kopf A, Masuda H, Matsuoka A, Moore GF, Otsubo M, Regalla C, Sakaguchi A, Sample J, Schleicher A, Sone H, Stanislowski K, Strasser M, Toki T, Tsuji T, Ujiie K, Underwood MB, Yabe S, Yamamoto Y, Zhang J, Sanada Y, Kido Y, Le Ber E, Saito S (2020) Expedition 358 summary. With contributions by Kanamatsu T. In: Tobin H, Hirose T, Ikari M, Kanagawa K, Kimura G, Kinoshita M, Kitajima H, Saffer D, Yamaguchi A, Eguchi N, Maeda L, Toczko S, and the Expedition 358 Scientists, NanTro- SElZE Plate Boundary Deep Riser 4: Nankai Seismogenic/ Slow Slip Megathrust. Proceedings of the International Ocean Discovery Program, 358: College Station, TX (International Ocean Discovery Program). https://doi.org/10.14379/iodp.proc.358.101.2020

Ujiie K, Hisamitsu T, Taira A (2003) Deformation and fluid pressure variation during initiation and evolution of the plate boundary décollement zone in the Nankai accretionary prism. J Geophys Res Solid Earth 108(B8):2398. https://doi.org/10.1029/2002JB002314

Underwood MB (2017a) Data report: clay mineral assemblages in slope basin sediments and mass-transport deposits at Sites C0018 and C0021, IODP Expeditions 333 and 338. In Strasser M, Dugan B, Kanagawa K, Moore GF, Toczko S, Maeda L, and the Expedition 338 Scientists, Proceedings of the Integrated Ocean Drilling Program, 338: Yokohama (Integrated Ocean Drilling Program). https://doi.org/10.2204/iodp.proc.338.207.2017

Underwood MB (2017b) Data report: clay mineral assemblages in cuttings from Hole C0002N, IODP Expedition 348, Nankai Trough accretionary prism. In: Tobin H, Hirose T, Saffer D, Toczko S, Maeda L, Kubo Y, and the Expedition 348 Scientists, Proceedings of the Integrated Ocean Drilling Program, 348: College Station, TX (Integrated Ocean Drilling Program). https://doi.org/10.2204/iodp.proc.348.203.2017

Underwood MB (2017c) Data report: clay mineral assemblages and illite/ smectite diagenesis in cuttings from Hole C0002P, IODP Expedition 348, Nankai Trough accretionary prism. In: Tobin H, Hirose T, Saffer D, Toczko S, Maeda L, Kubo Y, and the Expedition 348 Scientists, Proceedings of the
Integrated Ocean Drilling Program, 348: College Station, TX (Integrated Ocean Drilling Program). https://doi.org/10.2204/iodp.proc.348.204.2017 Underwood MB (2018) The origin of strata within the inner accretionary prism of Nankai Trough: Evidence from clay mineral assemblages along the NanTroSEIZE transect. The Island Arc, e12252. https://doi.org/10.1111/ iar.12252

Underwood MB, Guo J (2013) Data report: clay mineral assemblages in the Shikoku Basin, NanTroSElZE subduction inputs, IODP Sites C0011 and C0012. In: Saito S, Underwood MB, Kubo Y, and Expedition 322 Scientists, Proc. IODP 322: Tokyo (Integrated Ocean Drilling Program Management International, Inc.). https://doi.org/10.2204/iodp.proc.322.202.2013

Underwood MB, Guo J (2017) Data report: clay mineral assemblages in the upper Shikoku Basin, results from IODP Expedition 333, Sites C0011 and C0012. In: Henry P, Kanamatsu T, Moe K, and Expedition 333 Scientists, Proceedings of the Integrated Ocean Drilling Program, 333: Tokyo (Integrated Ocean Drilling Program Management International, Inc.). https:// doi.org/10.2204/iodp.proc.333.205.2017

Underwood MB, Guo J (2018) Clay-mineral assemblages across the NankaiShikoku subduction system, offshore Japan: A synthesis of results from the NanTroSEIZE project: Geosphere, 14, 5, 2009-2043. https://doi. org/10.1130/ges01626.1

Underwood MB, Song C (2016) Data report: clay mineral assemblages in cuttings from Hole C0002F, IODP Expedition 338, upper Nankai Trough accretionary prism. In: Strasser M, Dugan B, Kanagawa K, Moore GF, Toczko S, Maeda L, and the Expedition 338 Scientists, Proceedings of the Integrated Ocean Drilling Program, 338: Yokohama (Integrated Ocean Drilling Program). https://doi.org/10.2204/iodp.proc.338.206.2016

Usman MO, Masago H, Winkler W, Strasser M (2014) Mid-Quaternary decoupling of sediment routing in the Nankai Forearc revealed by provenance analysis of turbiditic sands. Int J Earth Sci 103:1141-1161. https://doi. org/10.1007/s00531-014-1011-z

Vrolijk P (1990) On the mechanical role of smectite in subduction zones. Geology 18(8):703-707

Wessel P, Smith WHF, Scharroo R, Luis J, Wobbe F (2013) Generic mapping tools: improved version released. Eos Trans AGU 94(45):409. https://doi. org/10.1002/2013EO450001

Yabe S, Fukuchi R, Hamada Y, Kimura G (2019) Simultaneous estimation of in situ porosity and thermal structure from core sample measurements and resistivity log data at Nankai accretionary prism. Earth Planets Space 71:116. https://doi.org/10.1186/s40623-019-1097-4

Yamaguchi A, Hirose T, Ikari M, Kanagawa K, Kimura G, Kinoshita M, Kitajima H, Saffer D, Tobin H, Eguchi N, Maeda L, Toczko S, Bedford J, Chiyonobu S, Colson TA, Conin M, Cornard PH, Dielforder A, Doan M-L, Dutilleul J, Faulkner DR, Fukuchi R, Guérin G, Hamada Y, Hamahashi M, Hong W-L, Ijiri A, Jaeger D, Jeppson T, Jin Z, John BE, Kitamura M, Kopf A, Masuda H, Matsuoka A, Moore GF, Otsubo M, Regalla C, Sakaguchi A, Sample J, Schleicher A, Sone H, Stanislowski K, Strasser M, Toki T, Tsuji T, Ujiie K, Underwood MB, Yabe S, Yamamoto Y, Zhang J, Sanada Y, Kido Y, Le Ber E, Saito S (2020) Site C0024. With contributions from Kanamatsu T. In: Tobin H, Hirose T, Ikari M, Kanagawa K, Kimura G, Kinoshita M, Kitajima H, Saffer D, Yamaguchi A, Eguchi N, Maeda L, Toczko S, and Expedition 358 Scientists, NanTroSEIZE Plate Boundary Deep Riser 4: Nankai Seismogenic/Slow Slip Megathrust. In: Proceedings of the International Ocean Discovery Program, 358: College Station, TX (International Ocean Discovery Program). https://doi.org/10.14379/iodp.proc.358.104.2020

\section{Publisher's Note}

Springer Nature remains neutral with regard to jurisdictional claims in published maps and institutional affiliations. 